Drosophila melanogaster protein kinase CK2 interacts with and phosphorylates the neurogenic repressor $\mathrm{m} 8$ resulting in the production of a novel eye phenotype

\author{
Regina L. Trott \\ West Virginia University
}

Follow this and additional works at: https://researchrepository.wvu.edu/etd

\footnotetext{
Recommended Citation

Trott, Regina L., "Drosophila melanogaster protein kinase CK2 interacts with and phosphorylates the neurogenic repressor 88 resulting in the production of a novel eye phenotype" (2005). Graduate Theses, Dissertations, and Problem Reports. 4201. https://researchrepository.wvu.edu/etd/4201

This Thesis is protected by copyright and/or related rights. It has been brought to you by the The Research Repository @ WVU with permission from the rights-holder(s). You are free to use this Thesis in any way that is permitted by the copyright and related rights legislation that applies to your use. For other uses you must obtain permission from the rights-holder(s) directly, unless additional rights are indicated by a Creative Commons license in the record and/ or on the work itself. This Thesis has been accepted for inclusion in WVU Graduate Theses, Dissertations, and Problem Reports collection by an authorized administrator of The Research Repository @ WVU. For more information, please contact researchrepository@mail.wvu.edu.
} 


\title{
Drosophila melanogaster Protein Kinase CK2 Interacts With And Phosphorylates The Neurogenic Repressor m8 Resulting In The Production Of A Novel Eye Phenotype
}

\author{
Regina L. Trott \\ Thesis \\ Submitted to the Eberly College of Arts and Sciences \\ West Virginia University \\ In Partial Fulfillment of the Requirements \\ For the Degree of \\ Master of Science \\ In \\ Cell and Molecular Biology \\ Committee Members: \\ Dr. Clifton Bishop, Chair \\ Dr. Philip Keeting \\ Dr. Kristine Krajnak \\ Department of Biology \\ Morgantown, WV \\ 2005
}

Key Words: Drosophila melanogaster, Protein Kinase CK2, Enhancer-of-split

Complex, Neurogenesis, m8, Phosphorylation 


\section{Abstract \\ Drosophila melanogaster Protein Kinase CK2 Interacts with and Phosphorylates the Neurogenic Repressor m8 Resulting in the Production of a Novel Eye Phenotype}

\section{Regina L. Trott}

Protein kinase CK2 is a serine/threonine protein kinase ubiquitously expressed in eukaryotic organisms. The enzyme is composed of $2 \alpha$ (catalytic) subunits and $2 \beta$ (regulatory) subunits. The minimum consensus site for CK2 phosphorylation is $\mathrm{S} / \mathrm{TXXD} / \mathrm{E}$, where "X" is any non-basic amino acid. Substrates so far identified include proteins associated with cell cycle regulation and development.

In Drosophila melanogaster, the Notch pathway activates members of the Enhancer-of-split Complex [E(spl)-C]. m8, which is a member of the E(spl)-C, was found to interact with and be phosphorylated by CK2. The physiological affects of CK2 phosphorylation were studied in vivo through the Gal4-UAS system. Flies with a reduced eye phenotype were identified in a cross between scaGal4 and the transgenic line $\mathrm{m} 8 \mathrm{~S}^{159} \mathrm{D}$. Two-hybrid analysis indicated $\mathrm{m} 8 \mathrm{~S}^{159} \mathrm{D}$ interacted significantly stronger with the proneural bHLH protein Atonal than either $\mathrm{m} 8$ or $\mathrm{m} 8 \mathrm{~S}^{159} \mathrm{~A}$. These results are the first indication that phosphorylation plays a role in the regulation of $\mathrm{E}(\mathrm{spl})-\mathrm{C}$ proteins and also the first implication of a role for CK2 during neurogenesis. 


\section{Acknowledgements}

There are many individuals who require my thanks over the course of this work. I must thank my committee members, Dr. Clifton Bishop, Dr. Philip Keeting and Dr. Kristine Krajnak for their guidance and support during this process.

I must also thank the members of Dr. Ashok Bidwai's lab, especially Dr. Bidwai and Umesh Karandikar. The majority of this work was conducted in Dr. Bidwai's lab. I am grateful to Dr. Bidwai for being given the chance to explore such an interesting project and to see such an exciting outcome. I am also grateful to Umesh for his friendship, support, and intellectual input during the course of this work. I learned an incredible amount during my association with the two of them.

I wish to thank Dr. Jerry Yin and Priscilla Wu of Cold Spring Harbor Laboratory for the use of their facilities and guidance during the creation of the transgenic flies. I would especially like to thank Priscilla for her patience and time during my learning process.

I would also like to thank my fellow graduate students, both past present, especially Frank Secreto, Hope Sasway, and Kristin Nestor for their friendship, support, and intellectual discussions.

And last, but far from least, I wish to thank my husband Steve and our son Joshua for all of their support (both technical and emotional), understanding, and encouragement over this sometimes incredibly long journey. 


\section{$\underline{\text { Table Of Contents }}$}

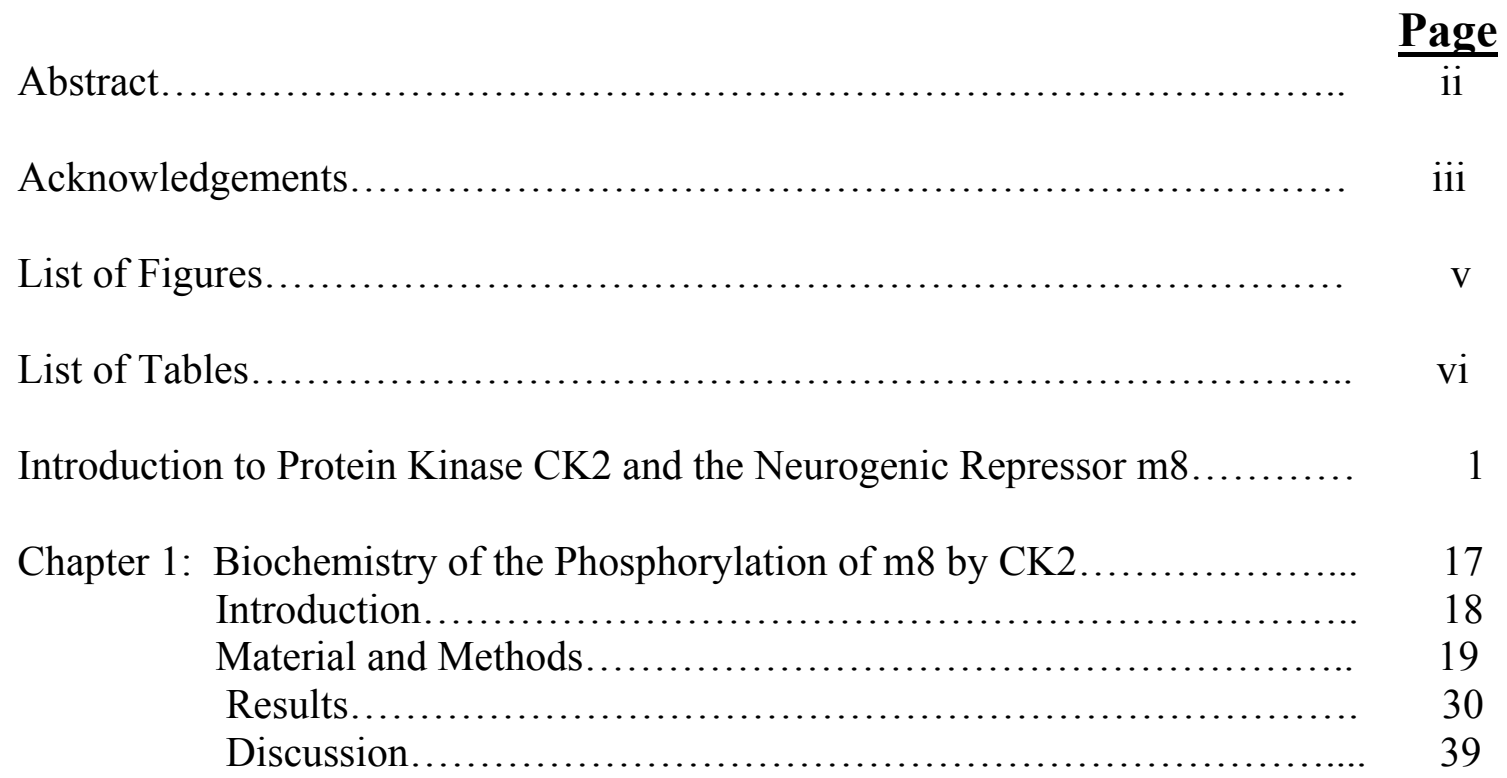

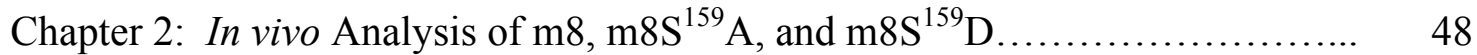

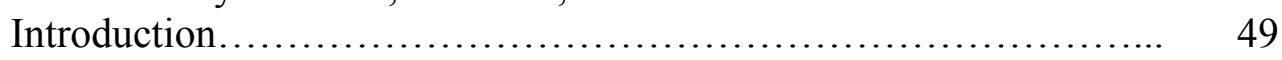

Material \& Methods........................................... 50

Results...................................................... 59

Discussion................................................... 71

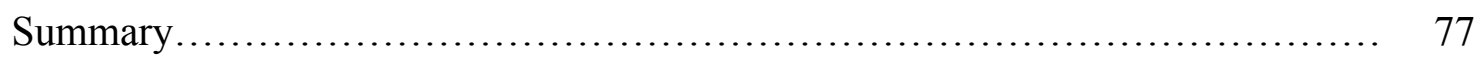

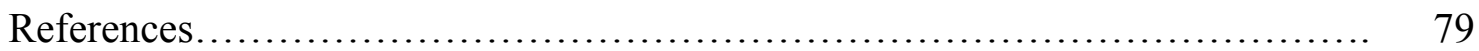




\section{List of Figures}

Figure Title Page

$1 \quad$ Schematic Representation of bHLH Protein m8 33

2 Phosphorylation of $\mathrm{m} 5, \mathrm{~m} 7, \mathrm{~m} 8$ by DmCK2 \& DmCK2 $\alpha \quad 34$

3 Interaction of m8 with Drosophila embryo CK2

4 Mapping of the Phosphorylation Site of m8 36

5 Yeast Two-Hybrid Interaction analysis of m8 Variants 37 with DmCK2 $\alpha$

$6 \quad$ Yeast Two-Hybrid Interaction analysis of m8 Variants 38 with Groucho

$7 \quad$ The Affect of m8 Variants on Scutellar Bristle 64

8 Electron Microscopy of Eye Phenotype 66

9 Yeast Two-Hybrid Interaction analysis of m8 Variants $\quad 70$ with Atonal 


\section{List of Tables}

$\begin{array}{lll}\text { Table } & \text { Title } & \text { Page } \\ 1 & \text { Mutagenic Primer Sequences for m8S }{ }^{159} \text { A and } 8 \mathrm{~S}^{159} \mathrm{D} & 29 \\ 2 & \text { Primer Sequences Utilized for Transgenic Flies } & 57 \\ 3 & \begin{array}{l}\text { Location of Transgenes and Designated Balancer } \\ \text { Chromosome }\end{array} & 58 \\ 4 & \text { Results of Crosses of m8 Variants and G455.2 } \\ 5 & \text { Results of Crosses of m8 Variants with scaGal4 } & 63 \\ 6 & \text { Results of Crosses of m8 Variants with gmrGal4 } & 67 \\ 7 & \text { Results of Crosses of m8 Variants with hGal4 } & 68 \\ 8 & \text { Results of Crosses of } \mathrm{m} 8 \text { Variants with sevGal4 } & 69\end{array}$


Introduction to Protein Kinase CK2 and the Neurogenic Repressor $\mathrm{m8}$ 


\section{General Properties of Protein Kinase CKII}

Protein kinase CK2 is a serine/threonine protein kinase ubiquitously expressed in eukaryotic organisms and located in both the cytoplasm and nucleus (Pinna 1997). This enzyme was one of the first protein kinases discovered over fifty years ago by Eugene P. Kennedy and George Burnett who observed the phosphorylation of casein by an enzyme present in liver mitochondria (Burnett et al. 1954; Pinna 1997). Burnett and Kennedy were also able to illustrate that this enzyme was capable of utilizing ATP as the phosphate donor and the amino acid residue undergoing phosphorylation was serine (Burnett et al. 1954; Pinna 1997).

CKII is composed of $2 \alpha$ (catalytic) and $2 \beta$ (regulatory) subunits with the $\beta$ subunits at the core of the complex (Pinna et al., 1997; Graham et al., 2000; Litchfield 2003). Most organisms contain two distinct alpha subunit isoforms with the exceptions being Drosophila melanogaster (Saxena et al, 1987), Caenorhabditis elegans (Hu et al, 1990) and Schizosaccharomyces pombe (Roussou et al, 1994). Recently, a third isoform designated as CK2 $\alpha$ ' has been identified in humans (Shi et al., 2001; Litchfield et al., 2003). While $\alpha$ subunit heterogeneity exists in most organisms, $\beta$ subuint heterogeneity does not and has only been found in Saccharomyces cerevisiae (Bidwai et al, 1994), Drosophila melanogaster (Bidwai et al, 1999), and Arabidopsis thaliana (Collinge et al, 1994). Three $\beta$ subunit isoforms have been found in Drosophila and are designated as DmCK2 $\beta$, DmCK2 $\beta$, and DmCK2 $\beta$ tes with the later two being found only in the testis (Kalmykova et al., 1997; Kalmykova 2002). It has also been shown recently that DmCK2 $\beta$ is necessary for proper mushroom body (involved in learning and memory processes) formation in flies (Jauch et al., 2002). This was the first time that an essential 
function of CK2 $\beta$ was demonstrated in a higher eukaryotic organism (Jauch et al., 2002). Where subunit heterogeneity has been observed, the enzyme may exist in complexes consisting of either two identical subunits or two different ones (Gietz et al., 1995; Litchfield 2003).

The functional significance of subunit heterogeneity is not known. For example, $\alpha$ and $\alpha^{\prime}$ are encoded for by two different genes (Yang-Feng et al., 1994; Wirkner et al., 1994). While the catalytic domains of these two isoforms exhibit about $90 \%$ identity, the carboxy-terminal domains of these subunits are completely unrelated (Litchfield et al., 1993). When comparing $\alpha$ or $\alpha^{\prime}$ among species, it has been found that the subunits are highly conserved as illustrated by a $98 \%$ identity between the $\alpha$ subunit of chicken and human and a 97\% identity between the $\alpha$ ' subunit of these same species (Lozeman et al., 1990; Maridor et al., 1991). Saccharomyces cerevisiae, for example, contains two $\alpha$ subunits (CKA1 and CKA2) (Glover 1998). If one of these is rendered non-functional the organism will survive but if neither one of the subunits is functional lethality results thus indicating that the enzyme is essential for viability (Glover 1998; Padmanabha et al., 1990; Snell et al., 1994). It has also been observed that temperature-sensitive alleles of either CKA1 or CKA2 exhibit different phenotypes indicating that functional overlap between these two subunits is not complete (Glover 1998). Similar results have been obtained in mice since if $\mathrm{CK} 2 \alpha^{\prime}$ is knocked out in this organism it is still viable but male offspring are sterile and exhibit a defect in spermatogenesis (Xu et al., 1999). Isoform specific substrates have been found for mammalian $\alpha$ with protein phosphatase $2 \mathrm{~A}$ being the first one identified (Heriche et al., 1997). Binding of this substrate was found to be dependant on the sequence HEHRKL found in $\alpha$ but not $\alpha^{\prime}$ ( Heriche et al., 1997). 
Another more recent identification of an interacting partner with $\alpha$ but not $\alpha^{\prime}$ is the peptidyl-prolyl isomerase Pin 1 which functions in cell division (Zhou et al., 1999; Messenger et al., 2002).

CK2 $\beta$ is highly conserved among organisms. The amino acid sequence is identical between birds and mammals and only differs from Xenopus laevis by a single (conserved) substitution (Maridor et al., 1991; Boldyrell et al., 1991; Heller-Harrison et al., 1989; Jedicki et al., 1992). The $\beta$ subunit of Drosophila melanogaster is $95 \%$ identical to that of humans (Bidwai 2000). This subunit has been found to stabilize the $\alpha$ subunit against thermal denaturation and proteolysis ( Bidwai et al., 1993). A five-fold stimulation of CK $2 \alpha$ has been attributed to the $\beta$ subunit for most substrates, but in a few cases (such as calmodulin) has been found to negatively regulate substrate phosphorylation (Bidwai et al., 1993). CK2 $\beta$ contains an autophosphorylation site in its amino terminus that had initially been classified as an intramolecular process based on kinetic data (Boldyreff et al., 1993; Litchfield et al., 1991). Current X-ray crystallographic data indicates that this phosphorylation site is located more than $40 \mathrm{~A}$ from either catalytic active site thereby raising questions as to how this phosphorylation actually occurs (Niefind et al., 2001). It has been proposed that this phosphorylation may be the result of the formation of higher-order CK2 structures that form between tetramers and have been observed in vitro but whose physiological significance remains unknown (Glover 1986; Valero et al., 1995).

Dimerization of the $\beta$ subunits occur via a zinc finger containing four cysteine residues (Chantalat et al., 1999). If mutations are introduced causing a disruption in the zinc finger, then dimerization of the subunits will not occur (Canton et 
al., 2001). In addition, in vitro evidence indicates that $\beta$ subunits with the above mentioned mutations will not interact with the $\alpha$ subunits indicating the possibility that $\beta$ subunit dimerization is needed for the formation of the holoenzyme (Canton et al., 2001; Graham et al; 2000).

Another region of CK2 $\beta$ that is important for the function of the enzyme is its carboxyl terminal domain (Litchfield 2003). This domain has been found to be necessary to enhance and stabilize the function of the $\alpha$ subunits (Marin et al., 1997; Sarno et al., 1999). X-ray crystallography has illustrated that this region of CK2 $\beta$ does indeed interact with CK2 $\alpha$ (Niefind et al., 2001).

While CK2 preferentially phosphorylates serines or threonines located near multiple acidic residues (most of which are downstream of the potential phosphorylation site), the minimum consensus site for phosphorylation has been determined to be $\mathrm{S} / \mathrm{T}$ XXD/E where X can be any non-basic amino acid (Pinna 1990; Pinna et al., 1997). It has also been shown that if acidic amino acid residues are located in either the $\mathrm{n}+1$ or $\mathrm{n}+2$ position from the putative phosphorylation residue, then phosphorylation of the serine or threonine by the enzyme is greatly increased (Pinna 1990). It has also been found that the aspartic or glutamic acid residue in the $n+3$ position can be replaced by phosphoserine, phosphothreonine, or phosphotyrosine (Roach 1991).

In addition to phosphorylating serine and threonine, CK2 has also been found to phosphorylate the yeast protein Fpr3 on a tyrosine residue (Wilson et al, 1997). Studies with synthetic peptides have indicated that kinetic parameters for the phosphorylation of tyrosine are much less favorable than those for serine (Marin et al., 1999). The amino acid sequence recognized for the phosphorylation has not been elucidated and in fact it is 
thought that the structural features of the protein accommodate phosphorylation in the case of tyrosine (Marin et al, 1999).

In addition to differing from other protein kinases in its ability to phosphorylate serine and threonine residues proximal to acidic residues, there are several other unusual properties that distinguish CK2 from other protein kinases (Pinna 1990; Litchfield 2003). In addition to utilizing ATP as the phosphoryl donor, protein kinase CK2 is also capable of utilizing GTP as the phosphoryl donor (Rodnight et al., 1964). ATP has been found to be the more efficient phosphoryl donor in the presence of $\mathrm{Mg}^{2+}$ while in the presence of $\mathrm{Mn}^{2+}$ GTP has been found to be the more efficient phosphoryl donor (Gatica et al., 1993). Another distinguishing property of $\mathrm{CK} 2$ is the enzymatic activity of the kinase is inhibited by polyanionic compounds such as heparin (Hathaway et al., 1980). CK2 is not known to be responsive to any second messengers but is activated by polyamines such as polylysine, spermine, and spermidine although the physiological relevance remains unknown (Meggio et al., 1992). This activation has been found to be mediated by a string of acidic residues within the $\beta$ subunit (Meggio et al., 1994).

For many years the intracellular targets of CKII and its methods of regulation remained unknown (Pinna 1994). In 1976 eIF3 was the first endogenous substrate of CK2 discovered (Traugh et al., 1976; Issinger et al., 1976; Pinna 1994;). Soon after this many more endogenous substrates of CKII were discovered and continue to be elucidated. These substrates include those that function in DNA replication and transcription such as DNA topoisomerase II, DNA ligase, serum response factor (SRF), c-Jun, and c-Myb (Corbett et al., 1992; Prigent et al., 1992; Marais et al., 1992; Lin et al., 1992; Luscher et al., 1990; Allende et al., 1995; Bergholtz et al., 2001); signal 
transduction proteins such as the insulin receptor and protein kinase C (Pinna 1990; Pinna et al., 1995; Meggio et al., 2003); protein synthesis factors including eIF4B and eIF5 (Pinna 1990; Allende et al., 1995; Meggio et al., 2003); and cytoskeletal and structural proteins such as $\beta$-Tubulin, spectrin, and troponin-T (Pinna 1990; Allende et al., 1995; Meggio et al., 2003). Not only have these proteins been found to interact with and be phosphorylated by CK2, but changes in the biochemical activity of some of them have been found as well (Allende et al., 1995). For example, c-Myb is phosphorylated at its amino-terminus by CK2 (Luscher et al., 1990; Allende et al., 1995). Experimental evidence has shown that phosphorylation of c-Myb at this site inhibits the DNA binding of c-Myb (Luscher et al., 1990; Allende et al., 1995). Oncogenically active forms of cMyb have been shown to lack this CK2 phosphorylation site (Luscher et al., 1990; Allende et al., 1995). Additionally, in mammalian cell lines the activity of CK2 has been found to vary in a cell cycle dependent manner (Bidwai 2000; Carroll et al., 1989). In Saccharomyces cerevisiae, CK2 is needed for the G1 and G2/M phases of the cell cycle and for adapting to M-phase checkpoints in response to DNA damage (Hanna et al., 1995; Toczyski et al., 1997).

Drosophila melanogaster protein kinase CK2 (herein referred to as DmCK2) was utilized in the studies for this thesis. DmCK2 is very similar to CK2 found in other organisms in that it is a tetramer composed of $2 \alpha$ and $2 \beta$ subunits, can utilize both ATP and GTP as phosphoryl donors, undergoes autophosphorylation of the $\beta$ subunit, phosphorylates both serine and threonine and is inhibited by heparin and stimulated by polylysine (Glover et al., 1983). Some proteins found previously to interact with and be phosphorylated by DmCK2 include the homeobox proteins Antennapedia and Engrailed, 
and the segment polarity protein Dishevelled (Jaffe et al., 1997; Bourbon et al., 1995; Hunter et al., 1997). In order to find interacting proteins of DmCK2, a yeast two-hybrid screen utilizing a Drosophila melanogaster embryonic cDNA library and CK2 $\alpha$ as the "bait" was conducted. One potential interacting substrate of CK2 $\alpha$ was found to be m7 (A. Bidwai, personal communication). $\mathrm{m} 7$ is a member of the Drosophila Enhancer of Split Complex whose gene products function as transcriptional repressors. This complex is at the end of the Notch pathway which functions during the process of lateral inhibition. Upon inspection of the sequences for other members of the $\mathrm{E}(\mathrm{spl})-\mathrm{C}$ it was found that $\mathrm{m} 5$ and $\mathrm{m} 8$ also contain potential CK2 phosphorylation sites in conserved regions. In hopes of creating a better understanding of this process, a discussion of the Notch pathway itself followed by a discussion of the $\mathrm{E}(\mathrm{spl})-\mathrm{C}$, its protein products and their functions will follow.

\section{Notch Pathway}

Expression of the E(spl)-C is regulated by the Notch pathway through lateral inhibition which is the process by which one cell prevents other cells from assuming a similar fate (Artavanis-Tsadonas et al. 1999; Castro et al. 2005). The Notch pathway has been most extensively studied during the process of neurogenesis in Drosophila (Poulson 1937; Artavanis-Tsakonas et al., 1995; Castro et al., 2005). At the beginning of this process there is an ectodermal monolayer containing approximately 1800 cells all of which have the potential to form epidermis and neural cells (Artavanis-Tsakonas et al., 1995; Wolpert 2002). This layer is referred to as the neuroectoderm (Artavanis-Tsakonas et al., 1995; Wolpert 2002). Within the neuroectoderm small groups of cells begin expressing proneural genes and these small groups of cells are referred to as proneural 
clusters (Skeath et al. 1992; Ruiz-Gomez et al. 1993; Martin-Bermudo et al. 1991). At this time all cells of the proneural cluster have the potential to become precursors of the nervous system (Cubas et al., 1991; Skeath et al., 1991; Artavanis-Tsakonas et al., 1995; Castro et al., 2005). One cell within this cluster expresses and accumulates proneural proteins to a greater extent than the other cells (Cabrera 1990; Doe et al., 1985;

Hartenstein et al., 1990; Simpson 1990). This cell will develop into a neuroblast and inhibit surrounding cells from assuming this same fate through the Notch pathway (Cabrera 1990; Doe et al., 1985; Hartenstein et al., 1990; Simpson 1990). This cell contains the Notch ligand, Delta, which is a single-pass cell surface transmembrane protein (Artavanis-Tsakonas et al. 1999). Delta interacts with the Notch receptor which is itself a single- pass transmembrane protein (Artavanis-Tsakonas et al. 1999). When Delta interacts with Notch, a signal is transmitted through the receiving cell (Castro et al., 2005). This signal includes the cleavage of the intracellular domain of Notch and its translocation to the nucleus of the cell (Struhl et al., 1998; Chan et al., 1998; Castro et al., 2005). The cleaved intracellular domain forms a complex with the transcription factor Suppressor of Hairless $[\mathrm{Su}(\mathrm{H})]$ which then functions to induce expression of target genes of the Notch pathway, i.e., members of the E(spl)-C (Castro et al., 2005). Cells where genes of the $\mathrm{E}(\mathrm{spl})-\mathrm{C}$ have been expressed and whose protein products accumulate will not assume a neuronal fate but instead will become dermoblasts (Jennings et al. 1994; Artavanis-Tsakonas et al., 1995; Castro et al., 2005; Wolpert 2002).

Both Notch and E(spl)-C are required to restrict neuroblast differentiation since organisms deficient in either of these develop an overabundance of neuroblasts (Skeath et al. 1992; Martin-Bermudo et al. 1995). If there is a mutation in the E(spl)-C then all 
cells of the proneural cluster will accumulate high levels of proneural proteins and adopt a neural fate resulting in hypertrophy of the nervous system and massive clusters of sensory organs in the peripheral nervous system (Artavanis-Tsakonas et al., 1995; Greenwald 1998; Jennings et al., 1999).

\section{Enhancer of Split Complex}

The Enhancer of Split Complex (from now on referred to as the E(spl)-C) is located on the third chromosome in region 96F (Schrons et al. 1992). These genes are referred to as the "neurogenic genes" based on their ability to restrict the number of neuroblasts in the nervous system and hypertrophy of the nervous system if mutated (Lehman et al., 1983). Initially, genetic analysis on individual members of this complex was difficult due to the failure to isolate single mutations within the genes, with the one exception being $\mathrm{E}(\mathrm{spl})^{\mathrm{D}}$ (which codes for a truncated form of $\mathrm{m} 8$ ), and the apparent "functional redundancy" of members of the complex (Tata et al., 1995; Klambt et al., 1989; Delidakis et al., 1991; Schrons et al., 1992). Experiments were conducted in which both $\mathrm{m} 7$ and $\mathrm{m} 8$ were deleted with the result being viable progeny (Delidakis et al., 1991; Schrons et al., 1992). This seemed to indicate that the remaining genes could compensate for the lost genes thus contributing to the idea of "functional redundancy" (Delidakis et al., 1991; Schrons et al., 1992). In addition to their roll in the developing nervous system, members of the $\mathrm{E}(\mathrm{spl})-\mathrm{C}$ have been found to contribute to such processes as oogenesis, myogenesis, eye development, and sensory bristle development (Corbin et al., 1991; Xu et al., 1992; Bate et al., 1993).

Thirteen transcripts have been found to be produced from this complex during embryogenesis, of which seven encode the basic helix-loop-helix proteins mA (also 
known as $\mathrm{m} \beta$ ), $\mathrm{mB}$ (also known as $\mathrm{m} \gamma$ ), and $\mathrm{mC}$ (also known as $\mathrm{m} \delta$ ), $\mathrm{m} 3, \mathrm{~m} 5, \mathrm{~m} 7$, and m8 (Klambt et al. 1989; Delidakis et al. 1992; Knust et al. 1992). m5, m7, and m8 were found to encode basic helix-loop-helix proteins that were highly conserved (Klambt et al. 1989). These three genes were also found to be expressed in almost identical patterns up to stage 9 of embryonic development (Knust et al. 1987). A fourth gene, designated as m3, has been found to be ubiquitously expressed (Knust et al. 1987). Three other genes designated as $\mathrm{m} \beta, \mathrm{m} \gamma$, and $\mathrm{m} \delta$ were later shown to be members of this complex as well and whose transcription products were not detected until stage 7 but then follow the same expression pattern of $\mathrm{m} 5, \mathrm{~m} 7$, and $\mathrm{m} 8$ (Knust et al. 1992). All seven genes of the $\mathrm{E}(\mathrm{spl})$ $\mathrm{C}$ are expressed in most of the cells of the neuroectoderm and are found exclusively within the regions from which neuroblasts segregate and correlates with epidermoblast fate (Knust et al. 1992). Once the neuroblasts have segregated, they are found to no longer contain these transcripts but they are still highly abundant in the epidermoblasts (Knust et al. 1992). It is during developmental stage 11 that the distribution of these transcripts begins to differ and by stage 15 they are no longer present (Knust et al. 1992). During imaginal development, Notch is required for the correct specification of many cells including sensory organs, wing margins and veins, and eye development (Parody et al., 1993; de Celis et al., 1994; de Celis et al., 1996). In context with this, mRNA for both $\mathrm{m} 8$ and $\mathrm{m} 7$ has been detected in cell clusters where sensory organ precursors (SOPs) arise (de Celis et al., 1996; Hinz et al., 1994; Lecourtois et al., 1995). When these genes are ectopically expressed, there is a loss of macrochaetae from the thorax (de Celis et al., 1996; Nakao et al., 1996). m8, mA, and mC have all been found in the eye disc with $\mathrm{m} 8 \mathrm{mRNA}$ being located in a stripe of cells approximately four to six 
cells wide spanning the furrow (de Celis et al., 1996; Cooper et al., 2000; Ligoxygakis et al., 1998). Over expression and mutation in the $\mathrm{m} 8$ allele $\left[\mathrm{E}(\mathrm{spl})^{\mathrm{D}}\right]$ greatly reduces ommatidial development in the eye (Nagel et al., 1999). mA mRNA has been detected in the leg discs at the presumptive joints whereas $\mathrm{m} 8, \mathrm{~m} 7, \mathrm{mB}$, and $\mathrm{mC}$ have been detected in clusters of cells in a pattern similar to that of the proneural genes achaete and scute indicating their association with sensory organ precursors (de Celis et al., 1996).

\section{E(spl) Proteins}

The protein products of all of these genes contain a proline residue in the basic region of their amino terminus (Knust et al., 1992). This region is followed by two clusters of hydrophobic amino acids that make up the amphipathic helices of the basic helix-loop-helix proteins (Knust et al. 1992). Two additional amphipathic helices (which have been designated as helices III and IV and are also referred to as the Orange domain) and an invariant sequence of four amino acids at the carboxy terminus consisting of tryptophan, arginine, proline and tryptophan (designated as the WRPW domain) are also found in these proteins (Knust et al., 1992). Experimental data has indicated that the WRPW motif, the region encompassing helices III and IV (referred to as the "Orange"

domain), and the region between helices IV and the WRPW motif appear to be critical for $\mathrm{E}(\mathrm{spl})$ protein function because if one of these regions is deleted from the protein the protein becomes non-functional (Giebel et al., 1997). It has also been found that if the bHLH domain is deleted from the protein, the protein can still function as a transcriptional repressor but at a reduced level, at least in the case of bristle development (Geibel et al., 1997). 
Many basic helix-loop-helix transcription factors mediate cell fate during development (Jennings et al., 1999; Jan et al., 1993; Lee et al., 1997). Helix-loop- helix proteins are classified according to their dimerization capabilities, DNA binding specificities, and tissue distribution (Murie et al., 1994; Massare et al., 2000). Due to the presence of the proline residue in the basic region $\mathrm{E}(\mathrm{spl})$ proteins are categorized as Class VI helix-loop-helix proteins (Klambt et al., 1989; Massari et al., 2000). While it was originally thought that the proline residue in the basic region would disrupt the $\alpha$-helical structure and therefore the recognition helix, it was later discovered that these proteins could still bind DNA but with a different binding site specificity from that of other bHLH proteins (Chen et al., 2000). E(spl) proteins $\mathrm{m} 5, \mathrm{~m} 7$ and $\mathrm{m} 8$ had previously been shown to bind to a sequence of DNA referred to as the "N" box (5'-CACNAG-3') (Oellers, et al., 1994; Tietze et al., 1992; Jennings et al., 1999). More recent data has indicated that all seven $\mathrm{E}(\mathrm{spl})$ proteins preferentially bind $\mathrm{E}_{\mathrm{B}}$ boxes (5'-CACGTG-3') as homodimers (Jennings et al., 1999; Giagtzoglou et al., 2005).

Some of the mechanisms that have been proposed to explain the antagonism between the proneural proteins and proteins of the $\mathrm{E}(\mathrm{spl})-\mathrm{C}$ include repression of the achaete-scute complex (AS-C) by the $\mathrm{E}(\mathrm{spl})$ proteins, direct protein-protein interactions, and competition for binding sites (Fisher et al., 1998; Jimenez et al., 1997; Nakao et al., 1996; Jennings et al., 1999). Experiments have been conducted where the WRPW motif in $\mathrm{m} 7$ has been replaced with an activation domain which illustrated that the $\mathrm{E}(\mathrm{spl})$ proteins could regulate the transcription of the proneural gene achaete (Jimenez et al., 1997; Jennings et al., 1999). Yeast two-hybrid analysis have demonstrated that $\mathrm{E}(\mathrm{spl})$ proteins and proneural proteins can interact with each other, for example $\mathrm{m} 8$ and $\mathrm{m} 5$ 
interact with Daughterless (Da) while $\mathrm{m} 3$ interacted with achaete, scute, asense, and atonal (Alifragis et al., 1997; Jennings et al., 1999). Experimental evidence also suggests that members of $\mathrm{E}(\mathrm{spl})-\mathrm{C}$ function by repressing the target genes of the proneural genes and to some extent repress the proneural genes themselves (Giagtzoglou et al. 2003). This has been illustrated, for example, by the observation that $\mathrm{m} 8$ only moderately affects the expression of the proneural achaete but seems to almost completely repress such downstream targets as asense (Giagtzoglou et al. 2003). Recruitment of E(spl) proteins onto target genes may occur by direct DNA binding but can also occur by binding to the DNA bound proneural proteins themselves (Giagtzoglou et al. 2003).

As mentioned earlier, the WRPW motif is required for the function of the $\mathrm{E}(\mathrm{spl})$ proteins. The proline residue within this motif has also been found to be essential since changing it to a leucine results in a non-functional protein (Geibel et al. 1997). This motif serves as a transcriptional repression domain recognized by the protein Groucho (gro) (Schrons et al., 1992; Paroush et al. 1994; Fisher et al. 1996; Giebel et al. 1997). The Gro gene is located distal to $\mathrm{m} 8$ in the $96 \mathrm{~F}$ region of chromosome three and while structurally unrelated to members of $\mathrm{E}(\mathrm{spl})-\mathrm{C}$ is required in conjunction with them to repress neurogenesis (Ziemer et al. 1988; Preiss et al. 1988). Gro, which does not contain a DNA binding domain, has been found to act as a co-repressor of transcription by binding to members of E(spl)-C (Schrons et al., 1992; Paroush et al. 1994; Fisher et al. 1996; Giebel et al. 1997). The carboxy terminus of Gro contains a region of approximately 40 amino acid tandem repeats which consists of characteristically placed tryptophan and aspartate residues and is referred to as WD repeats (Hartley et al., 1988; Chen et al., 2000). The WD repeats function as protein-protein interaction domains allowing Gro to bind to 
transcriptional repressors such as the E(spl) proteins (Jimenez et al., 1997; Chen et al., 2000).

As discussed earlier, protein kinase CK2 is a ubiquitously expressed enzyme found in eukaryotic organisms including yeast, flies, and humans. Within the cell, the enzyme has been found in both the cytoplasm and the nucleus. CK2 has been implicated in a number of cellular functions such as development and cell cycle regulation. The purpose of this work was to elucidate the physiological importance of CK2 phosphorylation on a substrate of the enzyme. The model system used for this investigation was Drosophila melanogaster. Drosophila melanogaster has the advantages of a short developmental time from embryo to adult (approximately 10 days when reared at $25^{\circ} \mathrm{C}$ ) and has been used extensively for genetic analysis. The $\mathrm{E}(\mathrm{spl})-\mathrm{C}$ protein $\mathrm{m} 8$ and the $\alpha$-subunit of Drosophila melanogaster had previously been shown to interact (A. Bidwai, personal communication; Trott et al. 2001). Upon examination of the amino acid sequence of $\mathrm{m} 8$, a putative CK2 phosphorylation site was found at serine 159. The first hypothesis of this thesis is that serine 159 is phosphorylated by Drosophila melanogaster protein kinase CK2 (now referred to as DmCK2) and this will be illustrated through phosphorylation reactions with both the $\alpha$ subunit and holoenzyme as well as site-directed mutagenesis which changes serine 159 to a non-phosphorylatable residue in one case and in the other to a residue that mimics constitutive phosphorylation. The second hypothesis of this thesis is that phosphorylation of serine 159 plays a functional role during Drosophila development, or more specifically, during bristle formation. As a neurogenic gene, ectopic expression of $\mathrm{m} 8$ has been shown to inhibit the development of bristles (which function as sensory organs) in flies. The function of phosphorylation on 
m8 will be explored through the utilization of the GAL4-UAS system developed by Andrea H. Brand and Norbert Perrimon (1993). This system makes use of the yeast transcription factor Gal4 to activate transgenic genes in Drosophila in a cell or tissuespecific manner (this system will be discussed in greater detail in Chapter 2). The GAL4UAS system has previously been used to study the function of the $\mathrm{E}(\mathrm{spl})$ proteins and has been found to be especially useful in cases where mutations in single genes have been difficult to obtain or as in the case of the $\mathrm{E}(\mathrm{spl})-\mathrm{C}$ where the products of other members seem to compensate for each other. It is hoped that this approach will help to elucidate another functional role of CK2 phosphorylation as well as to give a better understanding as to the role of the $\mathrm{E}(\mathrm{spl})-\mathrm{C}$ member $\mathrm{m} 8$. 


\section{Chapter 1: Biochemistry of the Phosphorylation of $\mathrm{m8}$ by CK2}




\section{Introduction:}

One of the purposes of this thesis was to characterize the interaction of a potential CK2 substrate. One such potential interactor was found as a result of a yeast two-hybrid screen conducted by Dr. Ashok Bidwai while at the University of Georgia. The yeast two-hybrid screen utilized Drosophila melanogaster CK2 $\alpha$ (DmCK2 $\alpha)$ and a Drosophila melanogaster embryo cDNA library (Trott et al., 2001). Briefly, DmCK2 $\alpha$ was fused to the Gal4 DNA binding domain (Gal4DB-DmCK2 $\alpha$ ) while the cDNA library was fused to the Gal4 activation domain (Gal4AD) and transformed into the yeast strain HF7C (Trott et al., 2001). Due to the genotype of the yeast, the cells were plated onto CDD medium lacking tryptophan, leucine, and histidine. Cells which grew on this medium were screened for the production of LacZ since this reporter has been incorporated into the genome of HF7C (Feilotter et al., 1994). The production of LacZ further indicated a putative interaction between $\mathrm{DmCK} 2 \alpha$ and a protein encoded by the cDNA library. One of the potential CK2 interactors found during this screen was the E(spl)-C derived protein $\mathrm{m} 7$ (Trott et al., 2001). Amino acid sequence analysis of this protein indicated a putative CK2 phosphorylation site in the carboxyl-terminal domain (Trott et al., 2001). Upon alignment of this sequence and other members of the E(spl)-C, it was found that in addition to $\mathrm{m} 7, \mathrm{~m} 5$ and $\mathrm{m} 8$ also contained a potential CK2 phosphorylation consensus site in their carboxyl-termini (Trott et al., 2001). What was also unique to these three proteins was the location of the putative CK2 phosphorylation site within a PEST domain. In order to determine whether or not these proteins were substrates of CK2, biochemical analysis including phosphorylation reactions, yeast two- 
hybrid interactions, GST-pulldowns as well as mapping of the phosphorylation site needed to be conducted and the results of these studies are presented in this chapter.

\section{Materials and Methods:}

\section{Purification of GST-fusion proteins:}

The open reading frame of the $\mathrm{E}(\mathrm{spl})$ proteins was subcloned as EcoRI-BamHI fragments into plasmids expressing these proteins as C-terminal fusion proteins with Schistosoma japonicum glutathione s-transferase (GST). Plasmids expressing GST, GST-m8, GST-m8S159A and GST-m8S159D were transformed into E. coli BL21 (DE3) harboring the plasmid pT-TRX (gift of S. Ishii, Laboratory of Molecular Genetics, Ibaraki, Japan). pT-TRX drives expression of thioredoxin. Thioredoxin has been found to increase the solubility and of eukaryotic proteins expressed in E. coli. (Yasukawa, T. et al. 1995). Purification of the fusion proteins was followed according to the protocol of Ausubel et al. (1995). 100ml cultures were grown in 2xYTA containing $150 \mu \mathrm{g} / \mathrm{ml}$ ampicillin and $15 \mu \mathrm{g} / \mathrm{ml}$ chloramphenicol to an $\mathrm{A}_{600}$ of 0.7 and induced with $1 \mathrm{mM}$ isopropyl-B-D-thiogalactoside for three hours at $30^{\circ} \mathrm{C}$ with vigorous shaking. All subsequent steps were conducted at $4^{\circ} \mathrm{C}$. Cells were harvested, resuspended in $8 \mathrm{ml}$ of phosphate-buffered saline (final concentrations of $1.4 \mathrm{M} \mathrm{NaCl} ; .027 \mathrm{M} \mathrm{KCl} ; .101 \mathrm{M}$ Na2HPO4; .018M KH2PO4, the $\mathrm{pH}$ adjusted to 7.3 , and the solution brought to a final volume of $1 \mathrm{~L}$ with deionized water) containing $0.1 \mathrm{mM}$ phenylmethylsulfonyl fluoride, $1 \mathrm{mM}$ EDTA, and $0.2 \%$ 2-mercaptoethanol and lysed by sonication. Phase contrast microscopy was used to ensure that greater than $95 \%$ of the cells had lysed. Triton-X 100 was added to the samples to a final concentration of $1 \%$ and mixed for three hours at $4^{\circ} \mathrm{C}$. Insoluble material was removed by centrifugation and the supernatant was passed 
twice through a column containing 1ml of glutathione-Sepharose 4B (Amersham Pharmacia Biotech). The column was washed with ten bed volumes of $1 \mathrm{x}$ phosphatebuffered saline, and bound protein was eluted with $5 \mathrm{ml}$ of $100 \mathrm{mM}$ reduced glutathione in 50mM Tris, $\mathrm{pH} 8.0$. The eluted protein was concentrated and exchanged into a final volume of approximately $0.5 \mathrm{ml}$ storage buffer (10mM Tris, $\mathrm{pH} 8.0,0.5 \mathrm{mM}$ EDTA, $5 \%$ glycerol, $150 \mathrm{mM} \mathrm{NaCl}$, and $0.1 \mathrm{mM}$ phenylmethylsulfonyl fluoride) using a Biomax-10K centrifugal filter device (Millipore). $5 \mu \mathrm{l}$ of $5 \mathrm{x}$ sample buffer $(312 \mathrm{mM}$ Tris-Cl, $\mathrm{pH} 6.8$, $10 \%$ SDS, $25 \% 2$-mercaptoethanol, and $40 \%$ glycerol) was added to $20 \mu 1$ of the purified protein and the sample boiled for 10minutes. The purity of the fusion proteins was determined by SDS-polyacrylamide gel electrophoresis [using a $12 \%$ running gel composed of $7.5 \mathrm{ml}$ of $1.5 \mathrm{M}$ Tris- $\mathrm{Cl}, \mathrm{pH} 8.8 ; 12.0 \mathrm{ml}$ of acrylamide solution at $30 \% \mathrm{~T}$, $2.7 \% \mathrm{C} ; 0.3 \mathrm{ml}$ of $10 \% \mathrm{SDS} ; 0.03 \mathrm{ml}$ of TEMED; $0.3 \mathrm{ml}$ of $10 \%$ APS and $9.87 \mathrm{ml}$ of distilled water; and a stacking gel composed of $2.5 \mathrm{ml}$ of $0.5 \mathrm{M}$ Tris- $\mathrm{Cl}, \mathrm{pH} 6.8 ; 1.3 \mathrm{ml}$ of acrylamide solution at $30 \% \mathrm{~T}, 2.7 \% \mathrm{C} ; 0.1 \mathrm{ml}$ of $10 \% \mathrm{SDS} ; 0.005 \mathrm{ml}$ of TEMED; $0.1 \mathrm{ml}$ of $10 \%$ APS; and $6.0 \mathrm{ml}$ of deionized water and the gel run at $35 \mathrm{~mA}$ for 4 hours and 20min](Laemmli, U.K. 1970; Ausubel et al. 1989). The gel was then stained in Coomassie-Blue (final concentration of 50\% methanol, $10 \%$ acetic acid, $0.02 \%$ CBB250 ) and destained (final concentrations of 5\% methanol and 10\% acetic acid). The concentrations of the fusion proteins were estimated from the stained gels relative to known standards (Mid-range protein molecular weight markers from Promega Corporation, Madison, WI). 


\section{Phosphorylation of GST-fusion proteins:}

The phosphorylation reactions were conducted at $25^{\circ} \mathrm{C}$ in $50 \mathrm{mM}$ Tris, $\mathrm{pH} 8.5$, $100 \mathrm{mM} \mathrm{NaCl}, 10 \mathrm{mM} \mathrm{MgCl}_{2}, 10 \mathrm{uM}$ ATP, $5 \mathrm{uCi}$ of $\left(\gamma_{-}{ }^{32} \mathrm{P}\right)$ ATP, and $2 \mu \mathrm{g}$ of various GST$\mathrm{E}(\mathrm{spl})$ fusion proteins in a total volume of $40 \mu \mathrm{l}$. The reaction was initiated with $5 \mu \mathrm{l}$ of the enzyme (either as the alpha subunit monomer or the holoenzyme) at a concentration of $8 \mu \mathrm{g} / \mathrm{ml}$ in $20 \mathrm{mM}$ Tris, $\mathrm{pH} 8.0,0.5 \mathrm{mM}$ EDTA, $200 \mathrm{mM} \mathrm{NaCl}, 10 \%$ glycerol, $0.5 \mathrm{mM}$ dithiothreitol, and $0.05 \%$ Triton-X 100 . Where appropriate, poly (DL) lysine was added to a final concentration of $100 \mu \mathrm{g} / \mathrm{ml}$. The reactions were terminated with $10 \mu 1$ of $5 \mathrm{x}$ sample buffer and boiled for 5 minutes. Samples were separated by SDS-polyacrylamide gel electrophoresis, stained with Coomassie Blue, and destained in a solution of 5\% methanol and 10\% acetic acid. The destained gels were then exposed to Kodak XAR-5 film at room temperature. Autoradiographs were developed using Kodak's GBX developer and fixer. Development was stopped by placing the film in a $1.3 \%$ acetic acid solution.

\section{In Vitro Interaction and Immunoblotting:}

$2.0 \mu \mathrm{g}$ of purified GST alone or GST-m8 were mixed with $25 \mu 1$ of glutathioneSepharose $4 \mathrm{~B}$ and incubated overnight at $4^{\circ} \mathrm{C}$. The Sepharose was pelleted by centrifugation for $1 \mathrm{~min}$ at $2000 \mathrm{Xg}$, and the beads were washed once with $1.5 \mathrm{ml}$ of wash buffer (final concentrations of 50mM Tris, pH7.5, 5mM EDTA, 150mM NaCl, $5 \%$ glycerol, $1 \mathrm{mM}$ Phenylmethylsulfonyl fluoride, and $0.1 \%$ Triton-X 100) to remove unbound GST fusion proteins. The washed Sepharose, containing the immobilized GST fusion proteins, was then incubated with 100ng of purified Drosophila embryo CKII for two hours at $4^{\circ} \mathrm{C}$. The Sepharose was pelleted by centrifugation for one minute at 2000 
$\mathrm{X} \mathrm{g}$ and the supernatant was recovered as unbound material. The pellets were washed two times for five minutes each time with $500 \mu l$ of wash buffer. Sepharose-bound (pellet) and unbound (supernatant) fractions were resolved by SDS-polyacrylamide gel electrophoreses (using a 12\% running gel as described above). The proteins were then electrophoretically transferred to nitrocellulose in Western transfer buffer (final concentrations $25 \mathrm{mM}$ Tris-base, $192 \mathrm{mM}$ Glycine, $20 \%$ methanol, $0.1 \%$ SDS, to final volume with deionized water) at $100 \mathrm{~mA}$ for $16 \mathrm{~h}$ (Towbin et al. 1979). The nitrocellulose was then stained in a $0.2 \%$ Ponceau solution (made in $1 \%$ acetic acid) with shaking for approximately $2 \mathrm{~min}$. The blot was then rinsed in deionized water and the proteins visualized. The blot was then incubated in $100 \mathrm{ml}$ of TS (consisting of $10.0 \mathrm{ml}$ of $1 \mathrm{M}$ Tris-Cl, $\mathrm{pH} 8.0$ and $8.766 \mathrm{~g} \mathrm{NaCl}$ per liter) for 30min with shaking. The TS solution was then poured off and $100 \mathrm{ml}$ of TBST (consisting of $20 \mathrm{ml} 1 \mathrm{M}$ Tris-Cl, $\mathrm{pH} 8.0 ; 17.53 \mathrm{~g}$ $\mathrm{NaCl} ; 20 \mathrm{~g} \mathrm{BSA} ; 5.0 \mathrm{ml}$ of $20 \%$ Tween- $20 ; 4.0 \mathrm{ml}$ of $10 \% \mathrm{NaN} 3$ to a final volume of $1 \mathrm{~L}$ with deionized water) was added and incubated at $4^{\circ} \mathrm{C}$ for $5.5 \mathrm{~h}$ with shaking. The TBST was poured off and $100 \mathrm{ml}$ of primary antibody solution (against DmCKII) at a dilution of 1:1000 was added to the blot and incubated at $4^{\circ} \mathrm{C}$ with shaking for approximately $16 \mathrm{~h}$. At this time the primary antibody was removed and the blot rinsed 3 times with $70 \mathrm{ml}$ of TBST for $15 \mathrm{~min}$ each time with shaking at room temperature. $100 \mathrm{ml}$ of secondary antibody (goat-rabbit IgG coupled to alkaline phosphatase, BioRad) at a dilution of 1:3000 was added to the blot and again incubated with shaking at room temperature for 1h. The secondary antibody was removed and the blot washed three times as above. The blot was briefly rinsed with AP buffer (consisting of 100ml 1M Tris-Cl, pH9.5; 5.844g $\mathrm{NaCl}$; and $5.0 \mathrm{ml} 1 \mathrm{M} \mathrm{MgCl} 2$ brought up to a final volume of 11 with deionized water). 
Immunoblots were visualized using nitro blue tetrazolium (NBT) and 5-bromo-4-chloro3-indoyl phosphate (BCIP) (Ausubel et al. 1989). A stock solution of NBT was made using $1 \mathrm{ml}$ of $70 \%$ DMF and $70 \mathrm{mg}$ of NBT. BCIP $(4.1 \mathrm{mg})$ was added to AP Buffer to give a final volume of $24.8 \mathrm{ml}$. NBT solution $(0.164 \mu \mathrm{l})$ was added to the $24.8 \mathrm{ml}$ of BCIP and the blot incubated in this final solution until the signal developed. The reaction was stopped by the addition of $0.5 \mathrm{M}$ EDTA, $\mathrm{pH} 8.0$ to give a final concentration of $50 \mathrm{mM}$. A fresh solution of $50 \mathrm{ml}$ of $50 \mathrm{mM}$ EDTA was then added to the blot.

\section{Site-Directed Mutagenesis:}

Serine 159 was changed to either an alanine or aspartic acid through the use of Quick-Change Site Directed Mutagenesis Kit (Stratagene). Complimentary primers for the mutagenesis are listed in Table 1 (synthesized at MGIF, University of Georgia, Athens, GA). The components of the PCR reaction consisted of 5.0 $\mu 1$ 10X Pfu polymerase buffer; $1.0 \mu \mathrm{l}$ (about 50ng) of pZEX-m8 wild type; $1.25 \mu \mathrm{l}(125 \mathrm{ng}$ ) of primer 1 and primer 2; $5.0 \mu l$ of dNTP (concentration of $8 \mathrm{mM}) ; 1.0 \mu l$ of Pfu polymerase at a concentration of $2.5 \mathrm{U} / \mu \mathrm{l}$; and $36.5 \mu 1$ water to give a final volume of $50.0 \mu \mathrm{l}$. The plasmid pZEX (gift of Ze'ev Paroush), which contained the complete open reading frame of $\mathrm{m} 8$, was subjected to the following PCR conditions: 1 cycle of $95^{\circ} \mathrm{C}$ for 2 minutes and 16 cycles of $95^{\circ} \mathrm{C}$ for 1 minute; $55^{\circ} \mathrm{C}$ for 1 minute; and $68^{\circ} \mathrm{C}$ for $14 \mathrm{~min}$. After the completion of PCR, the product was digested with the enzyme DpnI which recognizes methylated DNA as found in the parental plasmid but not in the PCR product in order to eliminate the parental wild-type plasmid but leaving the unmethylated mutant plasmid in tact. After this digest the PCR product was transformed in the E. coli strain DH5 $\alpha$ and selected on $\mathrm{LB}+\mathrm{Amp}^{150}$ media. An individual colony was selected and the $\mathrm{m} 8$ variant sequenced 
on both strands to confirm the success of the mutagenesis (sequenced at MGIF, University of Georgia, Athens, GA). The $\mathrm{m} 8$ variants were then subcloned in the plasmids pZEX and pEG202 into their EcoRI-Bam HI restrictions sites for the expression and purification of GST fusion protein and LEXA-fusion protein for the yeast two-hybrid analysis, respectfully.

\section{Isolation of Plasmid DNA:}

Plasmid DNA for yeast transformations was isolated from DH5 $\alpha$ cells through boiling mini-preps (Sambrook et al., 1989). Cultures were grown overnight in $3 \mathrm{ml}$ of Luria-Bertani (LB) medium (10.0g tryptone, $5.0 \mathrm{~g}$ yeast extract, $10.0 \mathrm{~g} \mathrm{NaCl}, \mathrm{pH} 7.0$, and volume adjusted to $1 \mathrm{~L}$ with deionized water) plus ampicillian $\left(\mathrm{AMP}^{150}\right.$ ) at $37^{\circ} \mathrm{C}$ and 225RPM. The next day $1.5 \mathrm{ml}$ of the cultures were transferred to $1.5 \mathrm{ml}$ eppendorf tubes. The cultures were centrifuged on maximum speed in a tabletop eppendorf centrifuge for $1 \mathrm{~min}$. The supernatants were aspirated off and $100.0 \mu 1$ of STET ( $8.0 \%$ sucrose, $0.5 \%$ Triton X-100, 50.0mM Tris $\mathrm{pH} 8.0,50.0 \mathrm{mM}$ EDTA pH 8.0, brought to a final volume of $200.0 \mathrm{ml}$ with deionized water) was added to each sample and vortexed. $100.0 \mu \mathrm{l}$ of STETL (STET with the addition of lysozyme to a final concentration of $2.0 \mathrm{mg} / \mathrm{ml}$ ) was next added and each sample gently inverted 6 times. The samples were then boiled in a water bath for $1 \mathrm{~min}$ and centrifuged as above for $20 \mathrm{~min}$. The pellets were removed with sterile toothpicks and $200.0 \mu \mathrm{l}$ of isopropanol was added to the supernatant and then vortexed. This solution was again centrifuged as above for $20 \mathrm{~min}$. The supernatants were poured off, the tubes inverted for $5 \mathrm{~min}$ and then placed in the $37^{\circ} \mathrm{C}$ incubator until dry. The pellets were resuspended in $100.0 \mu \mathrm{l}$ of TE, $\mathrm{pH} 8.0$ containing RNase $(1 \mu \mathrm{g} / \mathrm{ml})$ and incubated at $37^{\circ} \mathrm{C}$ for $30 \mathrm{~min}$. The integrity of the plasmid DNA was checked 
through a restriction enzyme digest consisting of $2.0 \mu$ of $10 \mathrm{x}$ TAS (at a final concentration of $325 \mathrm{mM}$ tris-acetate $\mathrm{pH} 7.9 ; 625 \mathrm{mM} \mathrm{KCH}_{3} \mathrm{CO}_{2} ; 100 \mathrm{mM}$ $\mathrm{Mg}(\mathrm{CH} 3 \mathrm{COO})_{2} \cdot 4 \mathrm{H} 2 \mathrm{O} ; 5 \mathrm{mM}$ DTT; $40 \mathrm{mM}$ spermidine (free base)), $0.5 \mu \mathrm{l}$ of EcoRI (10 units/reaction), 0.5 $\mu \mathrm{l} \mathrm{BamHI} \mathrm{(10} \mathrm{units/reaction)} \mathrm{and} \mathrm{2.0 \mu l} \mathrm{of} \mathrm{10x} \mathrm{BSA,} \mathrm{10.0} \mu$ l of plasmid DNA and brought up to a final volume of $20.0 \mu 1$ with sterile deionized water. The reaction was incubated in a $37^{\circ} \mathrm{C}$ water bath for $2 \mathrm{~h}$. The reaction was terminated with the addition of 5.0 $\mu 1$ 10X stop dye (final concentrations of $0.1 \mathrm{M}$ EDTA, $\mathrm{pH} 8.0 ; 2 \%$ SDS; $30 \%$ glycerol; pinch of Bromophenol blue and brought up to volume with deionized water) and the products run out on a $.8 \%$ agarose gel at $10 \mathrm{~mA}$. The gel was then stained with ethidium bromide $(10.0 \mu \mathrm{l}$ of stock solution at $5.0 \mathrm{mg} / \mathrm{ml}$ added to $150.0 \mathrm{ml}$ of deionized water).

Yeast transformations:

Transformation of yeast strains was conducted using the lithium acetate method (Ausubel et al., 1989). Yeast strains to be transformed were inoculated and grown in appropriate CDD media (complete dropout composed of $3.5 \mathrm{~g}$ yeast nitrogen base ( $\mathrm{AA}^{-}$ $\left./ \mathrm{AS}^{-}\right), 1.1 \mathrm{~g}$ of the amino acid mix containing SYFRIEDMTV, 20.0g dextrose, $5.0 \mathrm{~g}$ $\left(\mathrm{NH}_{4}\right)_{2} \mathrm{SO}_{4}, 800.0 \mathrm{ml}$ deionized water, $\mathrm{pH}$ adjusted to 6.2 with $\mathrm{NaOH}$, and brought up to a final volume of $1.0 \mathrm{~L}$ ) and supplemented with appropriate amino acids to maintain current plasmids. These cultures were grown at $30^{\circ} \mathrm{C}$ at $250 \mathrm{RPM}$ for about $24 \mathrm{~h}$. The $\mathrm{OD}_{600}$ of the cultures were checked and the appropriate volume needed to inoculate $50.0 \mathrm{mls}$ of YPD broth $(10.0 \mathrm{~g}$ yeast extract, $20.0 \mathrm{~g}$ peptone, $20.0 \mathrm{~g}$ glucose in total volume of $1.0 \mathrm{~L}$ deionized water) to a cell density of $2.0 \times 10^{7}$ was pelleted in a clinical centrifuge at setting five for five minutes, the media aspirated, and the cells washed with $1.0 \mathrm{ml}$ of 
YPD broth. The washed cells were pelleted as above and resuspended in 1.0ml of YPD. This resuspension was then transferred to $50.0 \mathrm{ml}$ of YPD and placed at $30^{\circ} \mathrm{C}$ at $250 \mathrm{RPM}$ until an $\mathrm{OD}_{600}$ of 1.0 was reached. The cells were then centrifuged in 50ml Oak Ridge tubes in a Sorvall SS-34 rotor at $22^{\circ} \mathrm{C}, 5000 \mathrm{RPM}$, for six minutes. The supernatants were carefully poured off and the cells resuspended in $25.0 \mathrm{ml}$ of sterile, deionized water then centrifuged again as above. The supernatants were poured off and the cells resuspended in $1.0 \mathrm{ml}$ of $100 \mathrm{mM}$ lithium acetate and transferred to a $1.5 \mathrm{ml}$ eppendorf tube. The samples were then centrifuged in a tabletop eppendorf microcentrifuge at 13,500 RPM for 1min. The supernatants were then pipetted off and the cells resuspended in $100 \mathrm{mM}$ lithium acetate to a final volume of $500.0 \mu \mathrm{l}$. The cells were briefly vortexed and $50 \mu \mathrm{l}$ of cells were transferred to a new $1.5 \mathrm{ml}$ eppendorf tube. The cells were again centrifuged as above and the supernatants removed. Added to the cells were then $240.0 \mu \mathrm{l}$ PEG, 36.0 $\mu 11 \mathrm{M}$ lithium acetate, $25.0 \mu \mathrm{l}$ of single-stranded salmon sperm DNA that had been boiled for $10 \mathrm{~min}$ and snap-cooled on ice slurry before use, and $50.0 \mu \mathrm{l}$ of plasmid DNA-water mix that contained about $0.8 \mu \mathrm{g}$ of plasmid DNA. These mixtures were then vortexed until the cells were completely resuspended. They were then incubated at $30^{\circ} \mathrm{C}$ in a water bath for $30 \mathrm{~min}$ and then heat-shocked in a $42^{\circ} \mathrm{C}$ water bath for $25 \mathrm{~min}$. After this incubation the cells were centrifuged as above for about $30 \mathrm{sec}$ and the transformation mix pipetted off. Each cell pellet was resuspended to $1.0 \mathrm{ml}$ of sterile, deionized water. Approximately $100.0 \mu \mathrm{ls}$ of each transformation was plated on the appropriate CDD selective media and placed in a $30^{\circ} \mathrm{C}$ incubator for about two days. Ten isolated colonies from each transformation were selected and patched out onto the appropriate CDD selective media and grown at $30^{\circ} \mathrm{C}$ for two days. 


\section{LexA-based two-hybrid interactions:}

Interactions between Drosophila melanogaster $\mathrm{CK} 2 \alpha$ and $\mathrm{E}(\mathrm{spl})$ proteins were analyzed in the LexA-based version of the yeast two-hybrid system developed in the laboratory of Roger Brent (Harvard University, Boston, MA). The yeast strain used for this analysis was EGY048 and is MATa, trp1, his3, ura3, leu2 and also contains a chromosomally integrated copy of the yeast LEU2 gene under control of six LexA operators, and a high copy plasmid pSH18-34 which expresses E. coli LacZ under the control of eight LexA operators (Estojak et al., 1995). Expression of the reporter genes LEU2 and LacZ is induced when the interacting complex is bound to the LexA-operators. Expression of the B42 Activation Domain (AD) fusion protein is under the control of a GAL-promoter. Therefore, reporter gene expression in an $\mathrm{AD}$ fusion protein dependent manner is observed only when the cells are grown in media containing galactose, but not glucose, as the sole carbon source. Yeast EGY048 containing plasmid pSH18-34 was transformed with a plasmid expressing the $\mathrm{B} 42$-derived $\mathrm{AD}$ alone or $\mathrm{AD}$-DmCKII $\alpha$ fusion protein using lithium acetate (see above). A single transformant was selected and subsequently retransformed with plasmids expressing LexA-m8S159A or LexA-m8S159D. At least three independent transformants were tested for the induction of the LEU2 gene on glucose and galactose dropout medium lacking leucine at $30{ }^{\circ} \mathrm{C}$ for four days. Cultures were also analyzed in triplicate for $\beta$-galactosidase (LacZ) activity using a solution-based assay.

\section{Liquid $\beta$-galactosidase Assay:}

Three clones were each inoculated into $2.0 \mathrm{ml}$ of CDG (complete dropoutgalactose) media and grown at $30^{\circ} \mathrm{C}$ and $225 \mathrm{RPM}$ for about $24 \mathrm{~h}$. $\mathrm{OD}_{600}$ was determined 
and the proper volume determined to inoculate $5.0 \mathrm{ml}$ of YPGAL (10.0g yeast extract, $20.0 \mathrm{~g}$ peptone, $20.0 \mathrm{~g}$ galactose) to an $\mathrm{OD}_{600}$ of 0.45 . The cells were then grown to $\mathrm{OD}_{600}$ between 0.6 and 0.8 with the actual OD for a given culture being recorded. When these $\mathrm{OD}_{600}$ were reached, $1.5 \mathrm{ml} \times 3$ were transferred to $1.5 \mathrm{ml}$ eppendorfs for each culture. The tubes were then centrifuged in a tabletop microcentrifuge (eppendorf) for 1.0min at 13,500RPM and the supernatants pipetted off. The cells were then resuspended in $1.5 \mathrm{ml}$ of 1x Z-buffer (10X Z-buffer which consists of $600 \mathrm{nM} \mathrm{Na}_{2} \mathrm{HPO}_{4}, 400 \mathrm{mM} \mathrm{NaH}_{2} \mathrm{PO}_{4}$,

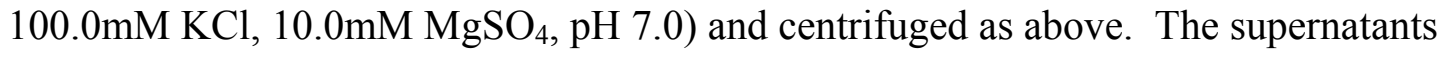
were then pipetted off and the cells resuspended in $300.0 \mu 1$ of $1 \mathrm{x} Z$ Z-buffer. $100.0 \mu 1$ of this resuspension was then aliquoted into three new $1.5 \mathrm{ml}$ eppendorf tubes. Cells were then frozen for $1.0 \mathrm{~min}$ in liquid nitrogen and placed in a $37^{\circ} \mathrm{C}$ water bath to thaw. This process was repeated two more times. B-mercaptoethanol was then added to 1x Z-buffer at a concentration of $.0027 \mathrm{ml} / \mathrm{ml}$ of Z-buffer and $700 \mu \mathrm{l}$ of this solution was added to each sample. To start the reaction, $160.0 \mu \mathrm{l}$ of o-Nitrophenyl- $\beta-\mathrm{D}-$ Galactopyranoside (ONPG at a concentration of $4.0 \mathrm{mg} / \mathrm{ml}$ dissolved in $1 \mathrm{x}$ Z-buffer) was added to each sample, the tube was inverted several times to mix the components, and the sample then placed in a $30^{\circ} \mathrm{C}$ water bath. When the sample had turned a light yellow color, $400.0 \mu 1$ of $1 \mathrm{M}$ $\mathrm{Na}_{2} \mathrm{CO}_{3}$ was added and the tube again inverted several times to stop the reaction. Each sample was then centrifuged as above for $10 \mathrm{~min}$ and the $\mathrm{OD}_{420}$ of the supernatants determined and recorded. LacZ activity (in Miller units) was calculated using the formula $1000 \times \mathrm{OD}_{420} /(\mathrm{t})(\mathrm{V})\left(\mathrm{OD}_{600}\right)$ where $\mathrm{t}=$ elapsed time and $\mathrm{V}=0.1 \mathrm{ml} \times$ concentration factor. 
$\underline{\text { Table 1. Mutagenic Primer Sequences for } \mathrm{m}^{8 \mathrm{~S}^{159} \mathrm{~A} \text { and } \mathrm{m8S}} \mathrm{S}^{159} \mathrm{D}}$.

\begin{tabular}{|c|c|}
\hline Prin & Sequ \\
\hline $\mathrm{m} 8$ & $5^{\prime}-\mathrm{C}$ \\
\hline & G-3' \\
\hline & \\
\hline $\mathrm{m} 8 \mathrm{~S}^{159} \mathrm{D} \mathrm{R}$ & ITCGTGATATCCGG-3' \\
\hline
\end{tabular}

The bold, underlined nucleotides are those involved in the change of serine 159 to either an alanine or aspartic acid. 


\section{$\underline{\text { Results }}$}

\section{E(spl)-C Protein $\mathrm{m8}$ is a bHLH Protein}

The characteristic domains of $\mathrm{m} 8$ include an amino-terminus basic helix-loophelix domain, an Orange domain composed of helices III and IV, a carboxyl-terminal PEST domain which contains the putative CK2 phosphorylation site, and the WRPW motif which is essential for the protein's interaction with Groucho as illustrated in Figure 1A. The amino acid sequence of $\mathrm{m} 8$ is illustrated in Figure 1B with the colors corresponding to the appropriate regions in Figure 1A (Uniprot, The Universal Protein Resource: http://www.pir.uniprot.org/cgi-bin/upEntry?id=P13098).

\section{Enhancer of Split proteins $\mathrm{m5}, \mathrm{m} 7$, and $\mathrm{m8}$ are phosphorylated by DmCK2 and} $\underline{\operatorname{DmCK} 2 \alpha}$

The purified fusion proteins GST, GST-m5, GST-m7, GST-m8, and GST-mC were subjected to phosphorylation by DmCK2 purified from embryos and DmCK2 $\alpha$ purified from a yeast expression system both in the presence and absence of polylysine as indicated in Figure 2. GST-mC is a bHLH protein also encoded by the E(spl)-C but does not contain a putative CK2 phosphorylation site. Neither GST alone nor GST-mC was phosphorylated by DmCK2 or DmCK2 $\alpha$ either in the absence or presence of polylysine

(Figure 2, Panels B, C, E, and F, lanes 1 and 5). $\mathrm{m} 5, \mathrm{~m} 7$, and $\mathrm{m} 8$ were phosphorylated by both the holoenzyme and the $\alpha$ subunit (Figure 2, Panels B and E, lanes 2, 3, and 4). While equivalent concentrations of fusion protein were used (Figure 2, Panels A and D), $\mathrm{m} 5$ was phosphorylated to a greater extent than $\mathrm{m} 7$ and $\mathrm{m} 8$ (Figure 2, Panels $\mathrm{A}$ and $\mathrm{D}$ ). There was also a greater degree of phosphorylation in the presence of the $\alpha$-subunit than with the holoenzyme (Figure 2, Panels A and D). When the phosphorylation reaction was conducted in the presence of polylysine, there was little change in the 
phosphorylation of $\mathrm{m} 5$ but an increase in the phosphorylation of $\mathrm{m} 7$ and $\mathrm{m} 8$ was observed (Figure 2, Panels C and F).

\section{Drosophila melanogaster CK2 forms a physical complex with m8}

The fusion proteins GST and GST-m8 were purified from Escherichia coli as described in the materials and methods. The fusion proteins were bound to glutathioneSepharose beads and DmCK2 added to the reaction. The pellet and supernatant fractions were run on a $12 \%$ SDS-PAGE gel and subjected to Western blot analysis with antisera that recognizes both subunits of DmCK2. As illustrated in Figure 3, both subunits were found in the supernatant fraction when the enzyme was added to GST, thus indicating the enzyme did not form a complex with this protein. However, both subunits were present in the pellet fraction after being incubated with $\mathrm{m} 8$ thus indicating $\mathrm{m} 8$ and $\mathrm{CK} 2$ form a physical complex.

\section{Serine 159 is the CK2 phosphorylation site of $\mathrm{m8}$}

Two variants of $\mathrm{m} 8$ were utilized. Through site directed mutagenesis, serine 159 was changed to either an alanine $\left(\mathrm{S}^{159} \mathrm{~A}\right)$ or an aspartic acid $\left(\mathrm{S}^{159} \mathrm{D}\right) . \mathrm{S}^{159} \mathrm{~A}$ is a nonphosphorylatable variant and $\mathrm{S}^{159} \mathrm{D}$ mimics constitutive phosphorylation, neither of which should be phosphorylated. The fusion proteins GST-m8, GST- $\mathrm{m} 8 \mathrm{~S}^{159} \mathrm{~A}$, and GST-m8S ${ }^{159} \mathrm{D}$ were purified and subjected to phosphorylation by DmCK2 and DmCK2 $\alpha$. Only GST-m8 was phosphorylated, indicating that serine 159 is the site of phosphorylation by DmCK2 (Figure 4, Panel B, Lanes 1 and 4). The purified fusion proteins that were subjected to the phosphorylation reaction are illustrated on the Coomasie Blue stained gel and their position indicated by the arrow (Panel A). 
Interaction of $\mathrm{m8}, \mathrm{m8S}^{159} \mathrm{~A}$, and $\mathrm{m8S}{ }^{159} \mathrm{D}$ with $\mathrm{DmCK} 2 \alpha$ through yeast two-hybrid analysis

LexA-m8, LexA-m8S ${ }^{159} \mathrm{~A}$, and LexA-m8S ${ }^{159} \mathrm{D}$ were transformed into the yeast strain EGYO48p harboring the plasmid pJG-DmCK2 $\alpha$. A liquid assay for $\beta$ galactosidase activity was performed using ONPG as substrate. As indicated by Figure 5, there was an approximately $50 \%$ reduction in the interaction of $\mathrm{m} 8 \mathrm{~S}^{159} \mathrm{~A}$ with $\mathrm{DmCK} 2 \alpha$ as compared to $\mathrm{m} 8$ with DmCK2 $\alpha$. The interaction of $\mathrm{m} 8 \mathrm{~S}^{159} \mathrm{D}$ with DmCK2 $\alpha$ was abolished.

Interaction of $\mathrm{m8}, \mathrm{m8S}^{159} \mathrm{~A}$, and $\mathrm{m8S}{ }^{159} \mathrm{D}$ with Groucho through yeast two-hybrid $\underline{\text { analysis }}$

LexA-m8, LexA-m8S ${ }^{159} A$, and LexA-m8S ${ }^{159} \mathrm{D}$ were transformed into the yeast strain EGYO48p. The resulting strains were then transformed again with the vector VP16-Gro. A liquid assay for $\beta$-galactosidase activity was performed using ONPG as substrate. Figure 6 indicates there are no significant differences between in the interaction of Groucho with any of the $\mathrm{m} 8$ variants. 
A.

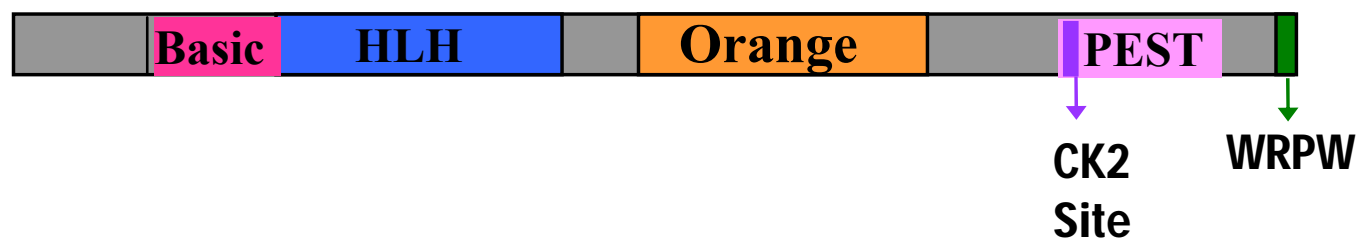

B.

MEYTTKTQIYQKVKKPMLERQRRARMNKCLDNLKTLVAELRGDDGILR

MDKAEMLESAVIFMRQQKTPKKVAQEEQSLPLDSFKNGYMNAVNEVSR

VMASTPGMSVDLGKSVMTHLGRVYKNLQQFHEAQSAADFIQNSMDCSS

MDKAPLSPASSGYHSDCDSPPPTPQPMQQPLWRPW

Figure 1. A) Schematic representation of the bHLH protein m8. B) Amino acid sequence of $\mathrm{m} 8$ with the regions of interest highlighted in colors corresponding to those used in (A) (Uniprot, The Universal Protein Resource: http://www.pir.uniprot.org/cgi-

$\underline{\text { bin/upEntry?id }=\mathrm{P} 13098 \text { ) }}$ 


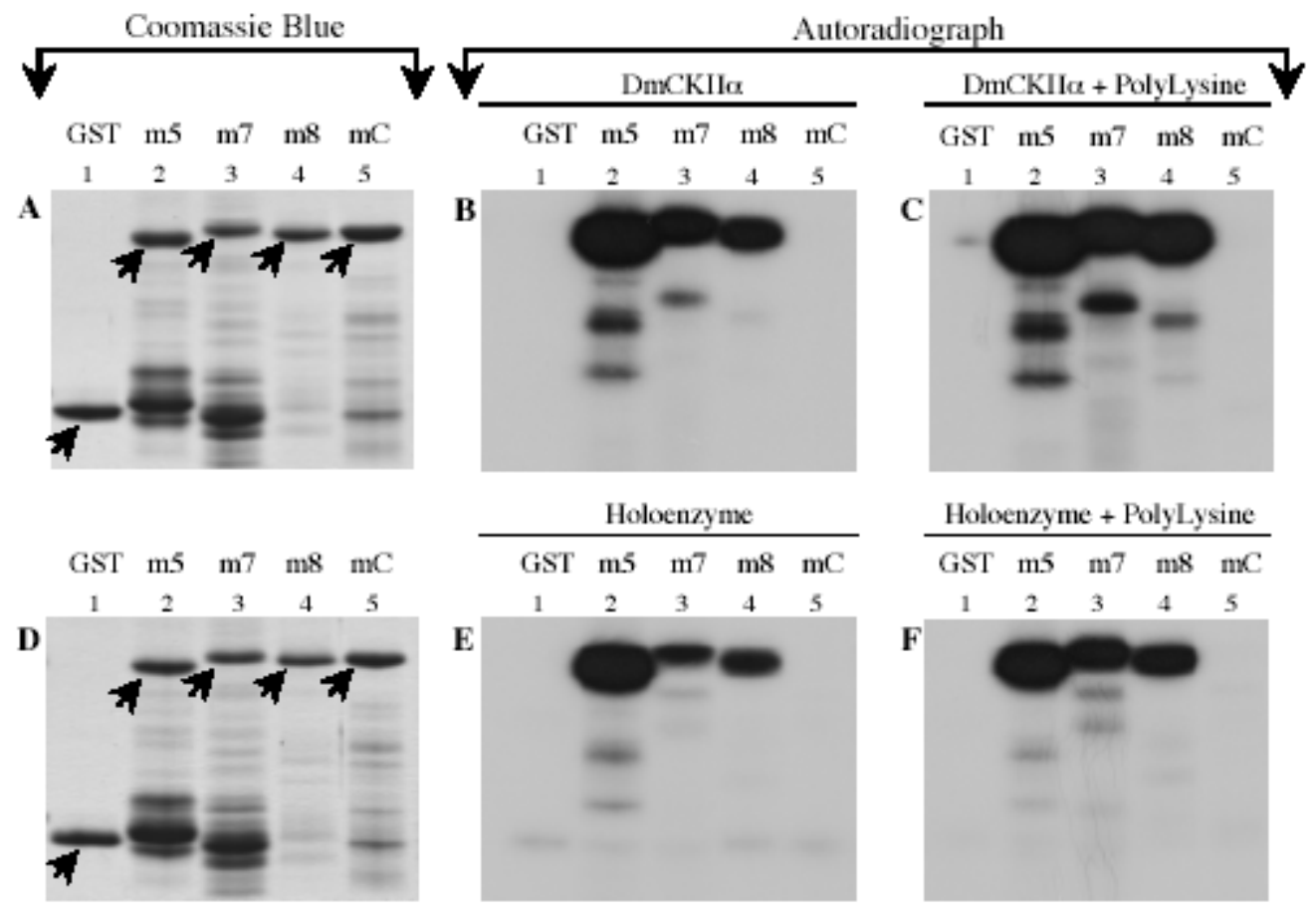

Figure 2. The phosphorylation of $\mathrm{m} 5, \mathrm{~m} 7$, and $\mathrm{m} 8$ by Drosophila melanogaster CK2 and CK2 $\alpha$. The indicated GST fusion proteins were purified and subjected to phosphorylation by either the holoenzyme or the $\alpha$ subunit and in the absence or presence of polylysine as indicated in the autoradiographs (Panels B, C, E, and $F$ ). Panels $A$ and $D$ are Coomassie Blue stained $12 \%$ SDSpolyacrylamide gels. The arrows indicate the positions of the fusion proteins on the gel. 


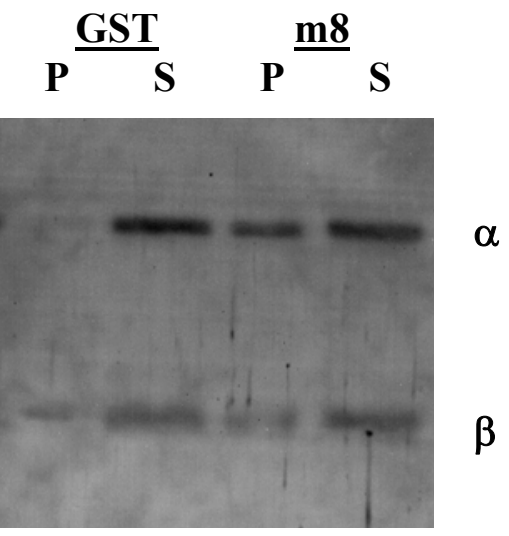

Figure 3. Interaction of $\mathrm{m8}$ with Drosophila melanogaster embryo CK2. GST and GST-m8 were immobilized on glutathione-Sepharose beads and incubated with Drosophila melanogaster CK2 purified from embryos. The pellets ( $P$ ) (containing the bound fusion proteins) were separated from the supernatants (S) (containing unbound material). The pellets and supernatants were subjected to Western blot analysis using antisera raised against Drosophila embryo CK2. The positon of the $\alpha$ and $\beta$ subunits are indicated. 


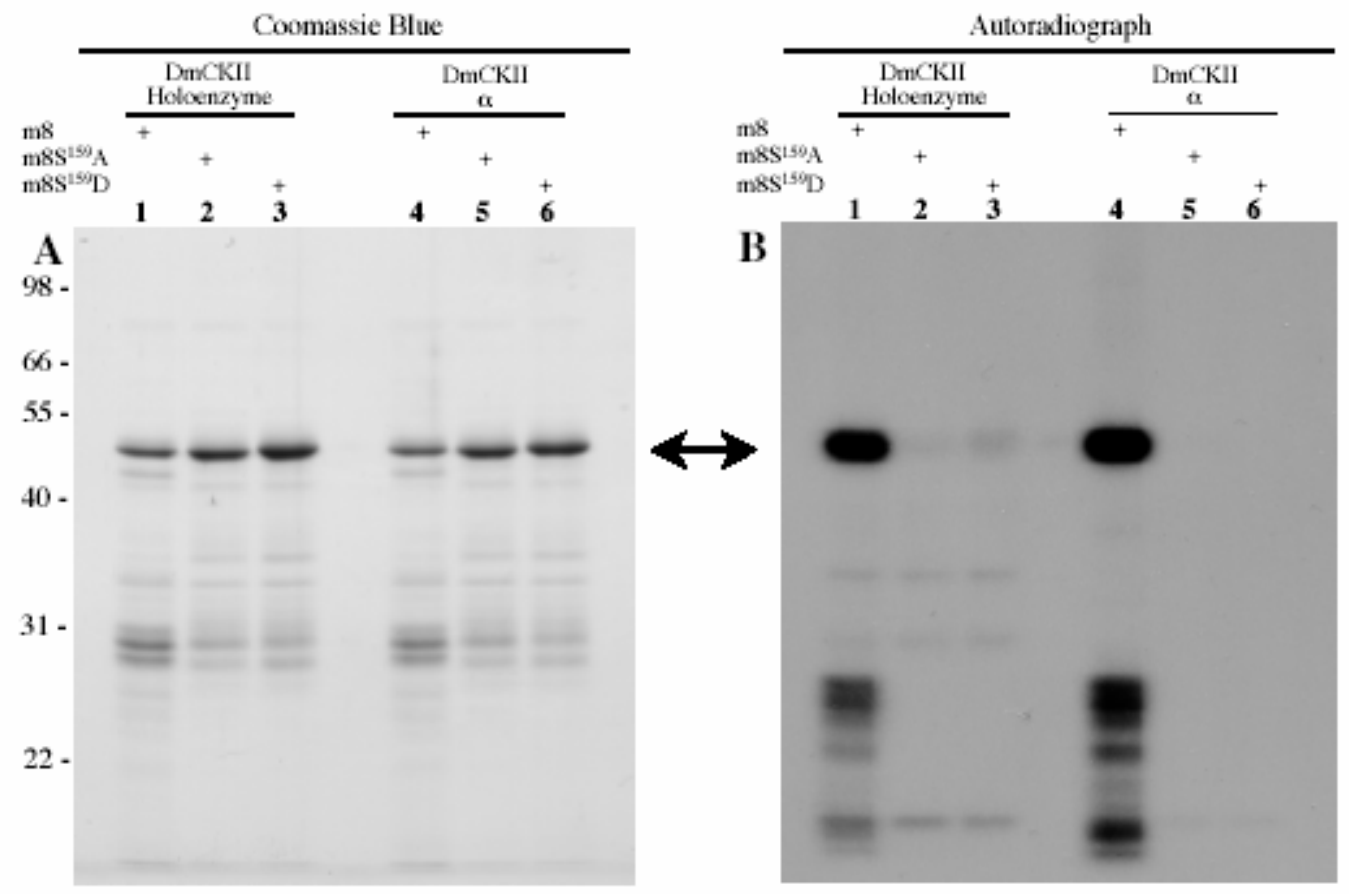

Figure 4. Mapping of the $\mathrm{m} 8$ phosphorylation site. Wild-type $\mathrm{m8}, \mathrm{m8S}^{159} \mathrm{~A}$, and $\mathrm{m8S}^{159} \mathrm{D}$ were subjected to phosphorylation by Drosophila melanogaster CK2 holoenzyme and $\alpha$ subunit as indicated. Panel $A$ represents the coomasie blue stained gel and Panel B the autoradiograph of the same gel. A "+" above the lane indicates the presence of that fusion protein and the arrow between the panels indicates the position of the GSTfusion protein. 


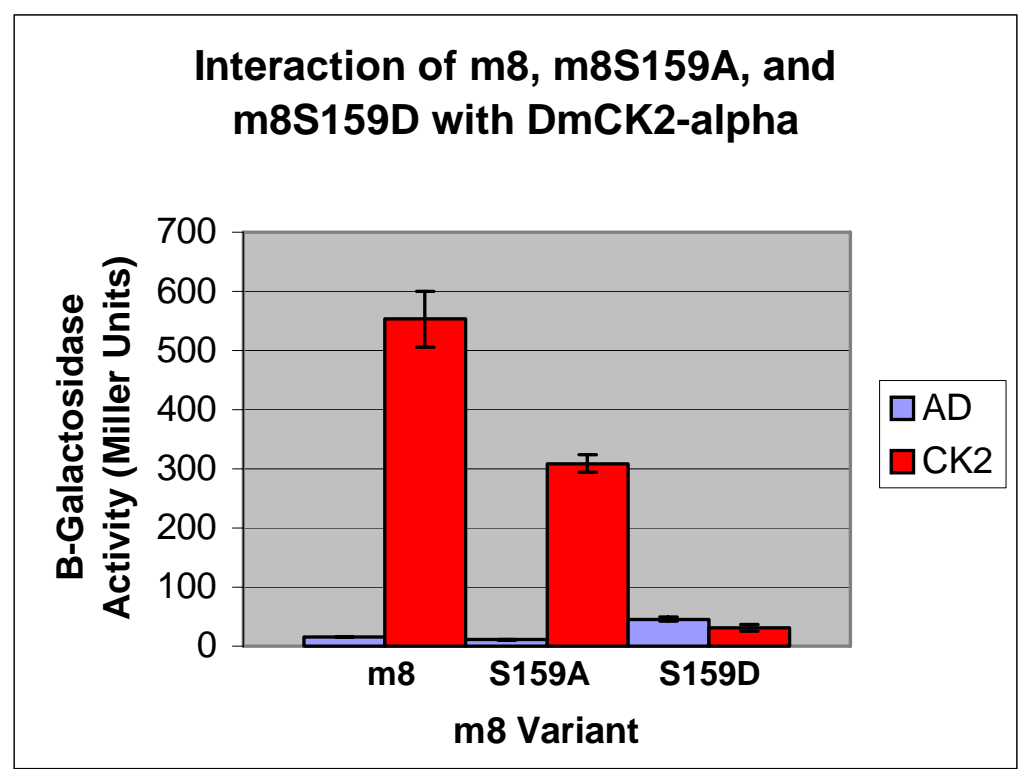

Figure 5. Yeast two-hybrid interaction analysis of $\mathrm{m8}, \mathrm{m}^{8} \mathrm{~S}^{159} \mathrm{~A}$, and m8S ${ }^{159} D$ with DmCK2 $\alpha$. The plasmids LexA-m8, LexA-m8S ${ }^{159} A$, and LexA$\mathrm{m8S}^{159} \mathrm{D}$ were transformed into the yeast strain EGYO48 (already harboring the $E$. coli Lac $Z$ expression plasmid) along with the B42 activation domain (AD) or the activation domain fused to DmCK2 $\alpha$. $\beta$-galactosidase activity is expressed in Miller Units and was determined by liquid assay as described in the materials and methods. Three independent colonies were used for each combination and run in triplicate. The graph represents the mean for a sample and the "error bars" the standard deviation. 


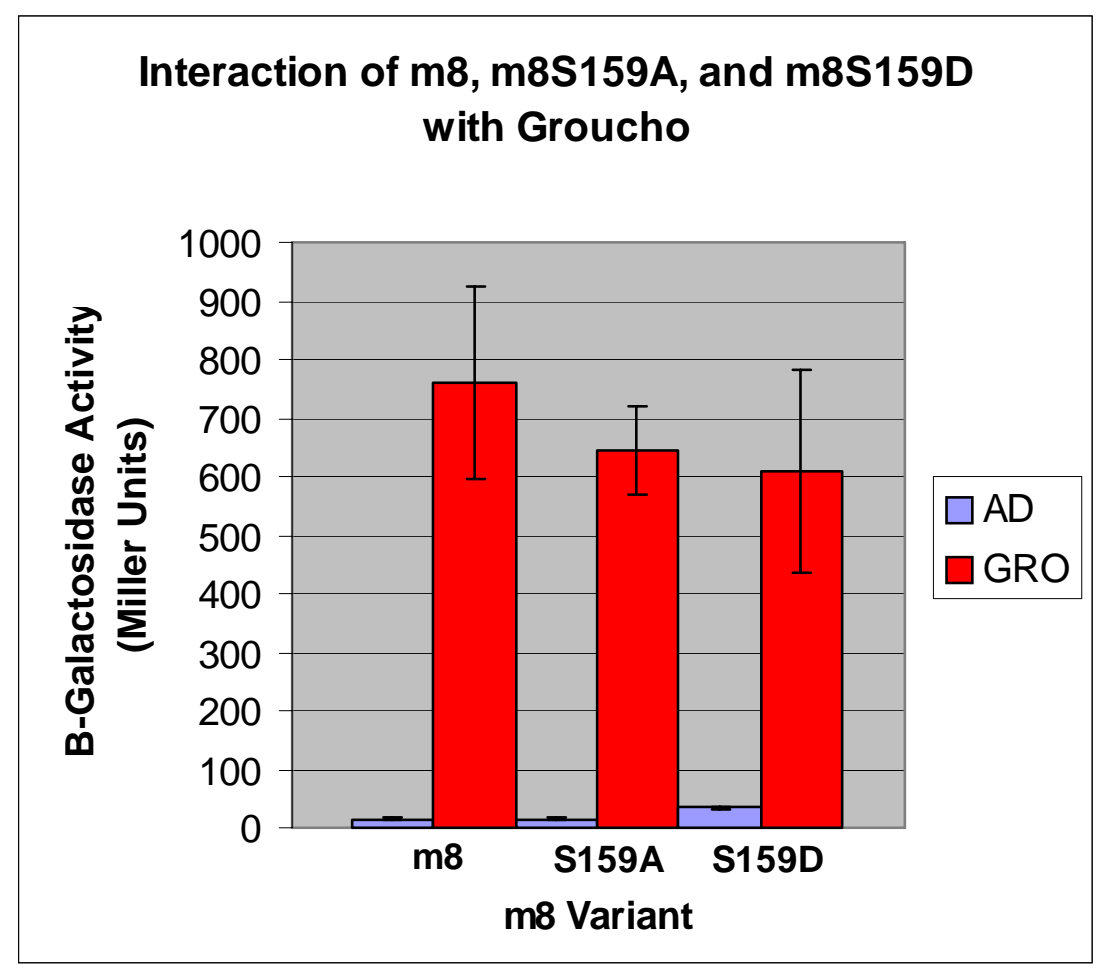

Figure 6. Yeast two-hybrid interaction analysis of $\mathrm{m8}, \mathrm{m8S}^{159} \mathrm{~A}$, and $\mathrm{m8S}{ }^{159} \mathrm{D}$ with Groucho. The plasmids LexA-m8, LexA-m8S ${ }^{159} A$, and $\operatorname{LexA} A-m 8 S^{159} D$ were transformed into the yeast strain EGYO48 (already harboring the $E$. coli Lac $\mathrm{Z}$ expression plasmid) along with the $\mathrm{B} 42$ activation domain (AD) or the activation domain fused to Groucho (GRO). $\beta$-galactosidase activity is expressed in Miller Units and was determined by liquid assay as described in the materials and methods. Three independent colonies were used for each combination and run in triplicate. The graph represents the mean for a sample and the "error bars" the standard deviation. 


\section{Discussion}

One of the potential interactors of the catalytic subunit of Drosophila melanogaster protein kinase CK2 identified during a yeast two-hybrid screen was the bHLH neurogenic repressor $\mathrm{m} 7$. Upon sequence alignment with other $\mathrm{E}(\mathrm{spl})-\mathrm{C}$ derived proteins, it was found that $\mathrm{m} 5, \mathrm{~m} 7$ and $\mathrm{m} 8$ all contained putative CK2 phosphorylation sites at a conserved serine residue within a PEST motif at the $\mathrm{C}$-terminal region of the protein (Trott et al., 2001). Other proteins derived from the $\mathrm{E}(\mathrm{Spl})-\mathrm{C}$ (such as $\mathrm{m} 3$ and $\mathrm{mC}$ ) do not contain a putative CK2 phosphorylation site in this region (Trott et al., 2001). Further interaction analysis through the yeast two-hybrid system supported the above (Trott et al., 2001). This analysis indicated that $\mathrm{m} 5, \mathrm{~m} 7$, and $\mathrm{m} 8$ all interacted strongly with DmCK2 $\alpha$, while $\mathrm{m} 3$ an $\mathrm{mC}$ (both of which do not contain putative CK2 consensus sites), did not (Trott et al., 2001).

The relevancy of the yeast two-hybrid interactions were further tested through phosphorylation reactions. The fusion proteins of GST-m5, GST-m7, GST-m8, and GST-mC as well as the GST tag were all subjected to phosphorylation by DmCK2 $\alpha$ (which mimics the situation found in the yeast two-hybrid system) and the holoenzyme (which mimics that found in vivo) (Trott et al., 2001). The results of this phosphorylation analysis indicated that $\mathrm{m} 5, \mathrm{~m} 7$, and $\mathrm{m} 8$ were all phosphorylated by DmCK2 and DmCK2 $\alpha$. However, neither the GST tag nor GST-mC were phosphorylated further supporting the interaction obtained through the yeast two-hybrid system.

Other aspects of this phosphorylation data are worthy of discussion. In addition to $\mathrm{m} 5, \mathrm{~m} 7$, and $\mathrm{m} 8$ being phosphorylated by $\mathrm{CK} 2$, it was observed that $\mathrm{m} 5$ was phosphorylated to a greater degree than $\mathrm{m} 7$ or $\mathrm{m} 8$ with both the $\alpha$ subunit and the 
holoenzyme. Previous analysis with synthetic peptides has indicated that additional acidic residues carboxyl-terminal to the $\mathrm{n}+3$ residue further enhances phosphorylation (Marin et al., 1999; Meggio et al., 1994). Therefore, the increased level of phosphorylation observed with $\mathrm{m} 5$ could be due to the presence of an aspartic acid in the $\mathrm{n}+4$ position (relative to the phosphorylated serine) that is absent in $\mathrm{m} 7$ and $\mathrm{m} 8$.

It was further observed that all three proteins exhibited stronger phosphorylation data with the $\alpha$ subunit than with the holoenzyme. While previous analysis has indicated that the $\beta$-subunit is capable of stimulating the activity of the $\alpha$-subunit approximately five-fold against most substrates including the RII subunit of cAMP-dependent protein kinase and the artificial substrate casein, it has been found to down-regulate the phosphorylation of some substrates such as calmodulin (Bidwai et al., 1993; Bidwai et al., 1992; Hu et al., 1990; Meggio et al., 1992). It has also previously been demonstrated that the polybasic compound polylysine is capable of overcoming this down-regulation by the holoenzyme and can stimulate phosphorylation of those substrates containing a minimal CK2 consensus site while only modestly stimulating more optimal substrates (Bidwai et al., 1993; Meggio et al., 1994). To test this concept on $\mathrm{m} 5, \mathrm{~m} 7$, and $\mathrm{m} 8$, phosphorylation reactions were conducted with polylysine in the presence of the $\alpha$ subunit or the holoenzyme. An increase in phosphorylation was observed for both $\mathrm{m} 7$ and $\mathrm{m} 8$ in the presence of either the holoenzyme or the $\alpha$ subunit but very little, if any, increase in phosphorylation was observed for $\mathrm{m} 5$ thus being in agreement with the literature.

After the above phosphorylation analysis, it was decided to focus on only one of the proteins for several reasons. Experimental evidence suggests that $\mathrm{m} 5, \mathrm{~m} 7$, and $\mathrm{m} 8$ 
are the $\mathrm{E}(\mathrm{spl})$ proteins that are most closely related to each other (Gigliani et al., 1996). Genetic evidence indicates that ectopic expression of $\mathrm{m} 7$ and $\mathrm{m} 8$ illicit the most severe suppression of bristle development (in the fly, bristles are part of the peripheral nervous system and function as mechanosensory structures) (Ligoxygakis et al., 1999). The contribution of $\mathrm{m} 5$ has been somewhat more difficult to determine and through the works of others, questions have arisen as to the stability and/or activity of the protein (Ligoxygakis et al., 1999). Genetic analysis on the function of $\mathrm{m} 8$, as well as a number of $\mathrm{m} 8$ variants including deletions of the WRPW motif, the orange domain, and the region between the orange domain including the PEST motif, has already been conducted using the GAL4-UAS system (which will be discussed in greater detail in Chapter 2) (Ligoxygakis et al., 1999; Giebel et al., 1997). Therefore, it was decided to expand on the knowledge already available on $\mathrm{m} 8$.

At this point it was decided to explore whether or not $\mathrm{m} 8$ was capable of forming a direct physical complex with DmCK2. This analysis was conducted to rule out the possibility that any endogenous yeast proteins were bridging the interaction between CK2 and $\mathrm{m} 8$ (Trott et al., 2001). GST fusion proteins were used for this analysis instead of Drosophila embryos since there are currently no antibodies available that specifically recognize $\mathrm{m} 8$ (Trott et al., 2001). This method utilized GST and GST-m8 bound to glutathione-Sepharose beads. The fusion proteins bound to the beads were then incubated with DmCK2 as described in the materials and methods. The results of this experiment illustrated that DmCK2 directly interacted with $\mathrm{m} 8$ but not GST thus further supporting an interaction between $\mathrm{m} 8$ and DmCK2 as suggested by the yeast two-hybrid data. 
In order to experimentally determine that serine 159 was the site of CK2 phosphorylation, site-directed mutagenesis was employed. Site directed mutagenesis allows the nucleotide sequence to be altered so as to introduce a change as small as a single base thus resulting in the incorporation of a different amino acid into the protein. In this case, serine 159 was changed to either an alanine or an aspartic acid. The substitution of alanine creates a protein that can no longer be phosphorylated by CK2 at this site, whereas the substitution of aspartic acid mimics constitutive phosphorylation of the protein but also cannot be phosphorylated by the enzyme. These mutants were purified as GST-fusion proteins and subjected to phosphorylation by DmCK2. The results indicated that neither $\mathrm{m} 8 \mathrm{~S}^{159} \mathrm{~A}$ nor $\mathrm{m} 8 \mathrm{~S}^{159} \mathrm{D}$ could be phosphorylated by the holoenzyme or the $\alpha$ subunit. Further analysis of these variants with the yeast two-hybrid system indicated an approximately 50\% decrease in the interaction between DmCK2 $\alpha$ and $\mathrm{m} 8 \mathrm{~S}^{159} \mathrm{~A}$ as compared to the interaction between $\alpha$ and the wild type $\mathrm{m} 8$. In the case of $m 8 S^{159} \mathrm{D}$ the interaction with DmCK2 $\alpha$ was virtually abolished, thus providing further support that serine 159 is the site of phosphorylation.

To summarize the data thus far presented, the experimental results indicate DmCK2 and DmCK2 $\alpha$ interact with and phosphorylate the $\mathrm{E}(\mathrm{spl})$ protein $\mathrm{m} 8$. Mapping of the CK2 phosphorylation site of $\mathrm{m} 8$ through site-directed mutagenesis and subsequent yeast two-hybrid analysis illustrates that serine 159 is the amino acid residue phosphorylated by CK2. These results are the first indication that $\mathrm{m} 8$ or any other members of the $\mathrm{E}(\mathrm{spl})-\mathrm{C}$ are potentially regulated by phosphorylation and one of the first implications of a role for CK2 in neurogenesis (Trott et al., 2001). Since E(spl) proteins 
have not previously been shown to be regulated by phosphorylation, the physiological significance of this phosphorylation is unknown.

As discussed earlier, $\mathrm{E}(\mathrm{spl})$ proteins interact with the co-repressor Groucho (GRO) (Giebel et al., 1997). This interaction is necessary for the antineurogenic function of these proteins. The WRPW motif, which consists of the last four amino acids of the carboxyl-terminal domain of the $\mathrm{E}(\mathrm{spl})$ proteins (amino acids 176-179 in the case of $\mathrm{m} 8$ ), is required for the interaction of Gro (Giebel et al., 1997). Previous data has indicated that the region containing serine 159 (located between the Orange domain and the WRPW motif) is required for the function of the protein (Giebel et al., 1997). One possible means of function for phosphorylation in this region could be to interfere with the binding of GRO, either by increasing or decreasing binding affinity. However, the yeast two-hybrid data collected for this analysis indicated no significant differences in the interactions of Gro with $\mathrm{m} 8, \mathrm{~m} 8 \mathrm{~S}^{159} \mathrm{~A}$ (non-phosphorylatable variant) or $\mathrm{m} 8 \mathrm{~S}^{159} \mathrm{D}$ (constitutive phosphorylation mimic), thereby indicating that this is most likely not the means of function for phosphorylation by CK2.

What are some possible functions for phosphorylation at serine 159? One way to elucidate the physiological importance of this phosphorylation during Drosophila development is through in vivo analysis. This can be accomplished through the use of the GAL4-UAS system which will allow the m8 variants to be expressed in a number of cell- and tissue-specific patterns and during particular time periods of Drosophila development. The resulting progeny can be screened for any mutant phenotypes that may help to elucidate the role of $\mathrm{CK} 2$ phosphorylation on $\mathrm{E}(\mathrm{spl})$ proteins. However, until that 
time, we can speculate as to some possible means of function for the phosphorylation of m8.

As mentioned above, serine 159 is found within a sequence of amino acids with a high PEST score (Delidakis et al., 1992; Trott et al., 2001). PEST sequences are rich in the amino acids proline $(\mathrm{P})$, glutamate $(\mathrm{E})$, serine $(\mathrm{S})$, and threonine $(\mathrm{T})$ and have been implicated in the turnover rate of proteins (Rogers et al., 1986; Rechsteiner et al., 1996; Liu et al., 1997). It has also been illustrated that many PEST domains contain serines and threonines near negatively charged amino acids, thus resulting in putative CK2 phosphorylation sites (Rogers et al., 1986; Rechsteiner et al., 1996; Li et al., 1999). This provides one possible mechanism for the function of phosphorylation of $\mathrm{m} 8$ (Trott et al., 2001). An example of the function of such a mechanism involves the Drosophila protein Cactus (Liu et al., 1997).

Cactus serves as an inhibitory protein of Dorsal by forming a complex with Dorsal and retaining it in the cytoplasm (Chasan et al., 1993). When the signal transduction pathway governing the function of Dorsal is activated, Cactus is degraded thereby freeing Dorsal and allowing translocation to the nucleus (Chasan et al., 1993). Dorsal then functions to establish embryonic polarity by suppressing dorsal-specific genes and activating ventral-specific ones (Chasan et al., 1993).

A critical step in the function of this pathway is the phosphorylation of Cactus (Liu et al., 1997). Previous analysis has illustrated that Cactus is phosphorylated by CK2 within a carboxyl-terminal PEST motif(Liu et al., 1997). Data also indicates that this phosphorylation is required for the degradation of Cactus and the signaling of Dorsal to the nucleus thus implicating CK2 in PEST domain function (Liu et al., 1997). 
The above information provides support for one possible function of phosphorylation by CK2 since the phosphorylation site is located within a PEST motif of m8. If this were the mechanism by which phosphorylation of these proteins function, then one would expect a non-phosphorylatable form of $\mathrm{m} 8\left(\mathrm{ie}, \mathrm{m} 8 \mathrm{~S}^{159} \mathrm{~A}\right.$ ) to remain in the cell for an extended period of time perhaps resulting in an increase of neurogenic inhibition. If this is the case, then constitutively phosphorylated $\mathrm{m} 8$ (which is mimicked by $m 8 S^{159} \mathrm{D}$ ) should exhibit an increased turnover rate and therefore not contribute to an increase in antineurogenic function (Trott et al., 2001).

CK2 has also been found to phosphorylate the Drosophila homeotic protein Antennapedia (Jaffe et al., 1997). Four CK2 sites have been mapped in Antennapedia, and two of these sites have been shown to be of particular importance to the wild type function of the protein, with one of these sites being located in the N-terminal region and the other in the C-terminus near the homeodomain (Jaffe et al., 1997). Experimental results indicate that the substitution of glutamic acid (which mimics constitutive phosphorylation as does aspartic acid) for serine at the CK2 sites greatly decreased the in vivo activity of the protein (Jaffe et al., 1997). The function of Antennapedia also depends on its ability to bind DNA together with another homeodomain protein, Extradenticle (Jaffe et al., 1997). The data indicates that the constitutively phosphorylated version of Antennapedia has a decreased interaction with Extradenticle of five to ten fold (Jaffe et al., 1997). It is also of interest to note that the CK2 site found in the N-terminal region is located within a PEST motif, thereby again raising the possibility that of regulation by CK2 in the form of protein degradation although this has not been experimentally tested (Liu et al., 1997). 
The alteration of protein-protein interactions by phosphorylation has also been illustrated with the proneural protein Scute (Alifragis et al., 1997). It has been shown that when serine 340 is changed to an aspartic acid (which, again, mimics constitutive phosphorylation), scute exhibits a greatly decreased interaction with the $\mathrm{E}(\mathrm{spl})$ protein m3 as analyzed through the yeast two-hybrid system (Alifragis et al., 1997). Although this serine is not a putative CK2 phosphorylation site, it is conserved in the proneual proteins Achaete and Lethal of Scute as well, and does illustrate the possibility that phosphorylation could affect binding between the proneural and neurogenic proteins (Alifragis et al., 1997). If protein-protein interactions are affected by the phosphorylation of $\mathrm{m} 8$, there are several possible outcomes. If interactions necessary for the function of the protein were decreased (as illustrated for Antennapedia and Scute), then one would expect not to see an increase in antineurogenic function. If protein-protein interactions necessary for the antineurogenic function of the protein were increased, one would expect to see an increase in antineurogenic effects.

There is the remote possibility that phosphorylation could affect the DNA binding of $\mathrm{m} 8$. This is seen as a remote possibility because the CK2 site is located in the C-terminus while the DNA binding domain is located in the $\mathrm{N}$-terminus and encompasses amino acids 12-25. Experimental evidence indicates that CK2 phosphorylates the Drosophila homeodomain protein Engrailed (Bourbon et al., 1995). In this case, phosphorylation by CK2 appears to increase the DNA binding affinity of Engrailed (Bourbon et al., 1995). Engrailed contains four CK2 phosphorylation sites that are serines located at positions 394, 397, 401, and 402 (Bourbon et al., 1995). These phosphorylation sites are located approximately fifty amino acids N-terminal to the 
homeodomain (Bourbon et al., 1995). Therefore, while this scenario is somewhat different from that encountered for $\mathrm{m} 8$, the possibility that CK2 phosphorylation could affect DNA binding perhaps through a conformation change, should not be ignored. If phosphorylation were to increase the DNA binding of $\mathrm{m} 8$, then there should be an increase in antineurognic function.

The above represent possible functions for the phosphorylation of $\mathrm{m} 8$, and $\mathrm{m} 5$ and $\mathrm{m} 7$ as well, since all three proteins contain the conserved serine and all three have been shown to undergo phosphorylation by CK2. Of the possibilities discussed above, the most plausible mechanism for regulation by $\mathrm{CK} 2$ phosphorylation seems to be that concerning the PEST domain and perhaps protein-protein interactions as illustrated in the case of Scute. Since this is the first time that phosphorylation has been implicated in the function of the $\mathrm{E}(\mathrm{spl})$ proteins, it is difficult to speculate as to the purpose of this phosphorylation. Therefore, it was thought more appropriate to address a number of possible scenarios as presented in the literature. The next step to determine whether or not this phosphorylation is critical to the function of $\mathrm{m} 8$ will be to study the expression of $\mathrm{m} 8$ and variants in transgenic flies. 


\section{Chapter 2: In vivo Analysis of $\mathrm{m8}, \mathrm{m8S}^{159} \mathrm{~A}$,}

and $\mathrm{m8S}^{159} \mathrm{D}$ 


\section{$\underline{\text { Introduction }}$}

While Chapter 1 explored the biochemistry of the phosphorylation of $\mathrm{m} 8$ by Drosophila melanogaster protein kinase CK2, this chapter explores the physiological significance of this phosphorylation. In order to study the effect of phosphorylation on the function of m8, the Gal4-UAS system developed by Andrea H. Brand and Norbert Perrimon (1993) was employed. This system makes use of the yeast activator Ga14 which has no endogenous targets in Drosophila (Brand et al., 1993). Gal4 can, however, activate transcription in flies if promoters have been introduced that contain Gal4 binding sites (Fischer et al., 1988; Brand et al., 1993). The Gal4 gene has been randomly inserted into the genome of Drosophila so that expression is driven from a number of genomic enhancers (Brand et al., 1993). This allows Gal4 to be expressed in many different celland tissue-specific patterns (Brand et al., 1993). While flies containing the Gal4 gene will produce this activator, transcription will not occur as there is no target gene to activate (Brand et al., 1993).

In order to create Gal4 responsive genes, a vector designated as pUAST contains five optimized Gal4 binding sites (Brand et al., 1993). A gene of interest may then be subcloned behind this binding site (Brand et al., 1993). This vector is then transformed into Drosophila embryos along with the "helper" plasmid pTURBO (Brand et al., 1993). pTURBO encodes a transposase whose function is to integrate the gene of interest into the genome of the embryo (Brand et al., 1993). When flies containing the Gal4 gene are mated to those containing the Gal4 binding sites fused to the gene of interest, the Gal4 activator will bind to the Gal4 UAS and activate transcription of the transgene in a tissue specific manner (Brand et al., 1993). 
This system of targeted gene expression has been used to elucidate the function of several genes. For example, this system has been used to determine the function of such genes as members of the E(spl)-C, including m8 (Giebel et al., 1997). In addition, this method has been used to express variants of $\mathrm{m} 8$ in order to determine critical regions for the function of the protein. These variants have been expressed in such restricted areas as the anlage of the scutellum and in much broader areas including the neuroectoderm (Giebel et al., 1997). Such expression was used to originally illustrate that the carboxylterminal region between the orange domain and the WRPW motif (which is the location of the CK2 site) was critical to the function of the protein (Giebel et al., 1997).

\section{$\underline{\text { Materials and Methods }}$}

$\underline{P C R}$ synthesis of Kozak and FLAG -tagged versions of $m 8, m 8 S^{159} A$, and $m 8 S^{159} D$ :

Primers were designed to create either a Kozak or a Kozak-FLAG-tagged version of the $\mathrm{m} 8$ variants. The addition of the Kozak sequence adds the nucleotides CAAC to the 5' end of the sequence. The Kozak-FLAG-tagged version not only adds the Kozak sequence but the amino acids DYKDDDDK as well. Both sets of primers introduced a 5' EcoRI and a 3' KPNI restriction site. The primer sequences (synthesized at MGIF, University of Georgia, Athens) are illustrated in Table 1. The PCR reaction consisted of 2.0ul (about 50.0ng) of template DNA (either pZEX-m8, pZEX-m8S ${ }^{159} \mathrm{~A}$, or pZEX$\left.\mathrm{m} 8 \mathrm{~S}^{159} \mathrm{D}\right) ; 2.0 \mathrm{ul}$ of the appropriate forward and reverse primers $(20.0 \mathrm{uM}) ; 5.0 \mathrm{ul} \mathrm{dNTP}$ (40mM); 10ul of 10X Pfu buffer; 1.0 $\mu \mathrm{l} \mathrm{Pfu} \mathrm{(concentration} \mathrm{of} \mathrm{2.5U/ \mu l)} \mathrm{and} \mathrm{80.0ul} \mathrm{sterile}$ deionized water for a final volume of 100.0ul. The PCR parameters used for this reaction were 1 cycle at $95^{\circ} \mathrm{C}$ for 2 minutes; 30 cycles at $95^{\circ} \mathrm{C}$ for 1 minute, $55^{\circ} \mathrm{C}$ for 1 minute, and $72^{\circ} \mathrm{C}$ for 2 minutes; and 1 cycle at $72^{\circ} \mathrm{C}$ for 3 minutes. The PCR products were then 
digested with the restriction enzymes EcoRI and KPNI (New England Biolabs), ligated into the vector pBluescript II SK $(+)$ (Stratagene), and transformed into DH5 $\alpha$. The plasmids were isolated through the use of a QIAprep mini kit (Qiagen), dried down in an eppendorf vacufuge, and sent out for sequencing (MGIF, University of Georgia, Athens, GA). Once the sequences were confirmed, the gene of interest was restriction digested from pBSII with EcoRI and KPNI (as described in chapter 1), run on a 2\% agarose gel, and purified using the GenElute gel purification kit from Sigma-Aldrich (St. Louis, MO). The inserts were ligated into the vector pUAST for expression in flies. The plasmid was purified using the QIAgen midi-prep kit. All purified plasmids were quantified using a Beckman Coulter DU 640 Spectrophotometer. The integrity of the DNA was confirmed through the use of a restriction digest with the enzymes BamHI and HindIII, run on a 1\% agarose gel at $15 \mathrm{~mA}$ for $7.5 \mathrm{~h}$, stained with ethidium bromide $(5.0 \mu 1$ of $5.0 \mathrm{mg} / \mathrm{ml}$ stock in $150 \mathrm{ml}$ of deionized water), and viewed with a BioRad Gel Imagining System.

\section{Preparation Of DNA For Embryo Injections}

$10.0 \mu \mathrm{g}$ of each pUAST-m8 variant was combined with $2.0 \mu \mathrm{g}$ of the transposase encoding plasmid, pTURBO (gift of J. Yin, Cold Spring Harbor Laboratory) in $2.0 \mu 15 \mathrm{M}$ $\mathrm{NaCl}, 300 \mu \mathrm{l}$ of absolute ethanol, and TE, $\mathrm{pH} 8.0$ to a final volume of $400 \mu 1$. The solutions were then placed at $-70^{\circ} \mathrm{C}$ for $15 \mathrm{~min}$. The samples were then centrifuged at room temperature in an Eppendorf tabletop centrifuge at 13,500RPM for 4min. The supernatants were poured off and the pellets washed in $170 \mu 1$ of $70 \%$ ethanol and centrifuged as above. The supernatants were pipetted off and the pellets speed vaced for $1 \mathrm{~min}$ to remove residual alcohol. $19.0 \mu \mathrm{l}$ of injection buffer (final concentration of $0.1 \mathrm{mM}$ sodium phosphate, $\mathrm{pH} 7.8 ; 5.0 \mathrm{mM}$ potassium chloride; and deionized water to a 
final volume of $10.0 \mathrm{ml}$ ) and $1.0 \mu \mathrm{l}$ of diluted green food coloring was added to each sample. To confirm the presence and integrity of both plasmids, samples from each prep were run on a $1 \%$ agarose gel at $80 \mathrm{~V}$ for $1 \mathrm{~h}$, stained with ethidium bromide, and visualized with a UV light source.

\section{$\underline{\text { Embryo Injections }}$}

Procedures followed were essential those employed by the laboratory of Jerry Yin, Cold Spring Harbor Laboratory, Cold Spring Harbor, NY. The line used for injection was Canton-S w ${ }^{1118}$ (from now on referred to as $2202 \mathrm{U}$ and a gift of J. Yin, Cold Spring Harbor Laboratory). Adult flies were placed in a cage (made from $400 \mathrm{ml}$ tricornered plastic beakers) attached to an egg plate $(50.0 \mathrm{~g}$ sucrose, $800.0 \mathrm{ml}$ deionized water, $17.6 \mathrm{~g}$ agar, final volume with distilled water to $1.0 \mathrm{~L}$ ) and baker's yeast paste (Fleishman's yeast mixed with water until desired consistency reached, i.e., about that of smooth peanut butter). Embryos were collected from the plates within 1h of the plate's placement. Embryos were removed from the plates by gently rinsing them with water and brushing them with a small, soft paintbrush into a Falcon cell strainer (70uM). To dechorionate the embryos, the strainer was placed in a $50 \%$ bleach solution for $2.5 \mathrm{~min}$ and rinsed with tap water for 1.0min. The embryos were spread out on a slide and positioned on 3M double-sided sticky tape (Manderscheid Equipment \& Supply, Chicago, IL) so their posterior ends were on the edge of the slide for injection. After about 20min the embryos were covered with a layer of halocarbon 700 oil (Halocarbon Products Corp., River Edge, NJ). This prevents the embryos from dessicating any further and allows them to obtain oxygen. (Note: the $20 \mathrm{~min}$ time period is variable and was used for a humidity of $50 \%,+/-5 \%$ and temperature of $18^{\circ} \mathrm{C}$ ). Embryo injections were 
conducted using an Eppendorf microinjector 5242, a Narishige micromanipulator, and Eppendorf femtotips. Time for injection and pressure of injection were highly variable depending on such conditions as humidity of the room, dessication state of the embryo, and injection needle. Needles were injected into the center of the posterior ends of the embryos where the germ cells are located. Volume injected was variable as well, but is typically somewhere between 1-2\% of the egg volume (Spradling 1986). Embryos were left on the slide at $18^{\circ} \mathrm{C}$, covered with halocarbon oil, until they developed into larvae. The larvae were then removed from the slide and transferred to a food vial. Separate food vials were used for each construct. All flies were reared on the following medium at $25^{\circ} \mathrm{C}: 15.0 \mathrm{~g}$ Bacto-Agar; $100.0 \mathrm{~g}$ Dextrose; $1.0 \mathrm{~g}$ potassium phosphate, dibasic; $50.0 \mathrm{~g}$ Brewer's Yeast; $25.0 \mathrm{ml}$ solution X (composed of $20.0 \mathrm{~g} / \mathrm{L}$ calcium chloride dihydrate); $25.0 \mathrm{ml}$ solution $\mathrm{Y}$ (composed of $20.0 \mathrm{~g} / \mathrm{L}$ ferrous sulfate heptahydrate); $150.0 \mathrm{ml}$ of solution Z (composed of $80.0 \mathrm{~g} / 1.5 \mathrm{~L}$ potassium sodium tartrate; $5.0 \mathrm{~g} / 1.5 \mathrm{~L}$ sodium chloride; $5.0 \mathrm{~g} / 1.5 \mathrm{~L}$ manganous chloride) all added to $800.0 \mathrm{ml}$ of distilled water. The mixture was autoclaved for $50.0 \mathrm{~min}$ and cooled to approximately $45^{\circ} \mathrm{C}$ before adding $10.0 \mathrm{ml} / \mathrm{liter}$ of a $10 \%$ Tegosept solution $(10.0 \mathrm{~g}$ tegosept into a total volume of $100 \mathrm{ml}$ 95\% ethanol). The food was poured into vials, plugged, and stored at $4^{\circ} \mathrm{C}$.

\section{Selection Of Transgenic Progeny}

Single matings were set for each adult that eclosed. Putative transgenic flies were crossed to $2202 \mathrm{U}$ of the opposite sex. Transgenic offspring of this cross were selected based on eye color. pUAST carries the mini-white gene as a marker; therefore, flies exhibiting eye color ranging from yellow to red contained the transgene and progeny with white eyes were discarded. Each transgenic fly represents a different insertion event and 
a unique transgenic line; therefore, individual matings for each of these flies was set with $2202 \mathrm{U}$ to maintain individual stocks.

\section{Mapping of transgene insertion:}

Transgene insertions were mapped to either the X, second, or third chromosome. This information was useful to show that the chromosomal location of the transgene was not an issue. To determine whether a transgene went in on the second or third chromosome, transgenic males (recombination does not occur in male flies) were crossed to virgin females containing either the balancer chromosome $\mathrm{CyO}$ or Tm6B, D. Virgin females of these stocks exhibited white eyes. $\mathrm{CyO}$ is a balancer for the second chromosome and contains the dominant mutation Curly which results in wings that are curled upward (Lindsley et al. 1972). Tm6B, D is a balancer for the third chromosome and contains the dominant mutation Dichaete that produces a phenotype where the wings are extended at an approximately $45^{\circ}$ angle (Lindsley et al. 1972). Progeny from each cross was selected based on the presence of eye color and the balancer as illustrated by the dominant mutation. These selected flies were then crossed to 2202U. If eye color and dominant mutation always segregated in the progeny, then the transgene was located on the homologue of the balancer. Balanced stocks were subsequently maintained as well as homozygous transgenic lines. One advantage to maintaining a balanced stock was that crossing over does not occur with the balancer chromosome.

Mapping to the X-chromosome was accomplished by crossing transgenic males to $2202 \mathrm{U}$ virgin females. If all resulting female progeny contained colored eyes and all males white eyes, then the transgene was located on the $\mathrm{X}$ since all male progeny get their only $\mathrm{X}$ from the female parent. The balancer Fm7a was used in this case. Fm7a 
males exhibit Bar eyes, yellow bodies, and pale orange eyes so based on these characteristics are easily distinguished from transgenic males that were used in crosses with GAL4 drivers.

The location of the transgene as well as balanced stocks are illustrated in Table 3 .

\section{Crosses with Gal4 lines:}

Males from at least three independent transgenic lines were mated with virgin females containing the following GAL4 drivers: G455.2 (a gift from A. Preiss, Universitat Hohenheim, Germany and was obtained as a balanced stock over $\mathrm{CyO}$ ) which expresses Gal4 in the anlage of the scutellum (Giebel et al., 1997); sca-Gal4 (a gift from A. Preiss, Universitat Hohenheim, Germany) which expresses Gal4 in the neural precursors of the embryo, the proneural clusters of the imaginal discs, and the morphogenetic furrow of the eye disc(Hinz et al., 1994; Nakao et al., 1996); sevGal4 (Bloomington Stock Center, Indiana Stock \#2023 as a balanced stock over CyO) which expresses Gal4 in the R3, R4, R1, R6, and R7 photoreceptor cells (Cooper et al., 2000); gmrGal4 (Bloomington Stock Center, Indiana Stock \#1104) which expresses GAL4 posterior to the morphogenetic furrow (Flybase, A Database of the Drosophila Genome: http://flybase.bio.indiana.edu/); and hGal4 (Bloomington Stock Center, Indiana Stock \#1734) which expresses Gal4 posterior to the morphogenetic furrow (Flybase, A Database of the Drosophila Genome: http://flybase.bio.indiana.edu/).

Crosses were set as described above and raised at $25^{\circ} \mathrm{C}$. Balanced stocks as well as homozygous lines were used for the crosses whenever possible. Progeny were examined for mutant phenotypes during various stages of development. 


\section{Scanning electron microscopy:}

Canton-Sw1118, m8, and m8S159D lines were crossed with sca-Gal4 and raised as above. At approximately the same developmental time points, newly eclosed flies were collected and decapitated in sodium phosphate buffer, $\mathrm{pH}$ 7.2. The heads were passed through a graded ethanol series $(25 \%, 50 \%, 75 \%$, and absolute). At this stage samples were taken to NIOSH (Morgantown, WV) to complete the process. After dehydration in ethanol, the heads were placed in hexamethyldisalizane and air-dried. The specimens were sputter coated and subjected to scanning electron microscopy utilizing a JEOL-6400 scanning electron microscope at an accelerating voltage of $20 \mathrm{kV}$.

\section{Yeast two-hybrid analysis:}

The vector B42-atonal (a gift from A. Preiss) was transformed into the yeast strain EGYO48 and into strains already harboring LexA, LexA-m8, LexA-m8S159A and LexA-m8S159D as well as the LacZ vector pSH18-34 as described in the material and methods section of Chapter 1. Transformants were plated onto the appropriate CDD media and incubated at $37^{\circ} \mathrm{C}$ for three days. At least three isolated colonies were selected for the liquid $\beta$-galctosidase assay as described in the materials and methods section of Chapter 1. 
Table 2: Primer Sequences Utilized For Transgenic Flies.

\begin{tabular}{|l|l|}
\hline Primer Name & Primer Sequence \\
\hline $\begin{array}{l}\text { KOZ-m8 Forward } \\
\text { Primer }\end{array}$ & $\begin{array}{l}\text { GGG AAT TCC AAC ATG GAA TAC ACC ACC AAG } \\
\text { ACC CAG }\end{array}$ \\
\hline $\begin{array}{l}\text { KOZ-m8 Reverse } \\
\text { Primer }\end{array}$ & GGG GTA CCT TAC CAG GGG CGC CAC AAG GG \\
\hline $\begin{array}{l}\text { FLAG-m8 } \\
\text { Forward Primer }\end{array}$ & $\begin{array}{l}\text { GGG AAT TCC AAC ATG GAC TAC AAG GAC GAT } \\
\text { GAC GAT AAG GAA TAC ACC ACC AAG ACC CAG }\end{array}$ \\
\hline $\begin{array}{l}\text { FLAG-m8 } \\
\text { Reverse Primer }\end{array}$ & GGG GTA CCT TAC CAG GGG CGC CAC AAG GG \\
\hline
\end{tabular}

The Kozak sequence is underlined.

The FLAG-Tag is in bold. 
Table 3: Location of Transgenes and Designated Balancer Chromosome

\begin{tabular}{|l|l|l|}
\hline Transgenic Stock & Chromosome of Insertion & Balancer \\
\hline Km8-1 & 2 & CyO \\
\hline Km8-2 & 3 & Tm6B,D \\
\hline Km8-3 & X & FM7a \\
\hline Fm8-1 & 3 & Tm6B,D \\
\hline Fm8-2 & 3 & Tm6B,D \\
\hline Fm8-3 & X & Fm7a \\
\hline FSA-1 & 2 & CyO \\
\hline FSA-2 & 3 & Tm6B,D \\
\hline FSA-3 & X & Fm7a \\
\hline KSD-1 & 2 & CyO \\
\hline KSD-2 & 2 & Cyo \\
\hline KSD-3 & X & Fm7a \\
\hline FSD-1 & 3 & Tm6B,D \\
\hline FSD-2 & 2 & CyO \\
\hline FSD-3 & 2 & CyO \\
\hline
\end{tabular}

$$
\begin{aligned}
& \text { K=Kozak sequence }+ \text { transgene } \\
& \text { F=Kozak }+ \text { FLAG }+ \text { Transgene } \\
& \text { m8=wild type m8 } \\
& \text { SA }=\text { m8S }^{159} \mathrm{~A} \\
& \mathrm{SD}=\mathbf{m 8 S}^{159} \mathrm{D}
\end{aligned}
$$




\section{$\underline{\text { Results }}$}

\section{$\underline{\mathrm{m8}, \mathrm{m8S}}{ }^{159} \mathrm{~A}$, and $\mathrm{m8S} \mathrm{S}^{159} \mathrm{D}$ affect scutellar bristle development}

Males from the stock $2202 \mathrm{U}$ as well as transgenic lines expressing $\mathrm{m} 8, \mathrm{~m} 8 \mathrm{~S}^{159} \mathrm{~A}$, or $\mathrm{m} 8 \mathrm{~S}^{159} \mathrm{D}$, were crossed to females of the line $\mathrm{G} 455.2$ (as described in materials and methods) that expresses Gal4 in the anlage of the scutellum (Giebel et al., 1997). The flies were raised on standard medium (see materials and methods) at $25^{\circ} \mathrm{C}$. As indicated in Table 4 and Figure 7, resulting progeny of the cross between 2202U males and G455.2 females contained four scutellar bristles indicative of wild type flies. On the other hand, progeny resulting from the cross between transgenic males and G455.2 females all exhibited a loss of scutellar bristles. In the case of wild type m8, this result was consistent with results previously obtained (Giebel et al., 1997). The result seems to indicate that the phosphorylation state of $\mathrm{m} 8$ is not critical to bristle development (at least in the case of scutellar bristles) as $\mathrm{m} 8$ represents the wild type protein, $\mathrm{m} 8 \mathrm{~S}^{159} \mathrm{~A}$ a nonphosphorylatable version, and $\mathrm{m} 8 \mathrm{~S}^{159} \mathrm{D}$ a mimic of constitutive phosphorylation.

Table 4 also indicates two different versions of the transgenes were used (these were used in all subsequent crosses as well). Transgenic flies containing either a "Kozak" sequence or a sequence encoding a "FLAG tag" on the amino terminus (which also contained a Kozak sequence) were utilized during this analysis. Both versions were used for several reasons. Initially, FLAG tagged versions were created with the idea of conducting Western blot analysis to show that the proteins of interest were being produced. The Kozak versions contain a Kozak sequence (CAAC) that has been shown to enhance translation of the protein (J. Yin, personal communication). During embryo transformations, the Kozak-m $8 \mathrm{~S}^{159} \mathrm{~A}$ version did not result in any transformed progeny. 
The Kozak versions that did result in transformed progeny were analyzed in crosses along with the FLAG tagged versions to see if comparable results were obtained. While more than three independent lines were used for each variant for all crosses, this analysis will take into account the use of only three lines. As can be seen in Table 4 (and Tables 5-8 as well), comparable results were indeed obtained for both transgenic versions, thereby validating their use. Initially, there had been some concern as to whether or not the FLAG tag would interfere with the basic region of the protein since the sequence of the FLAG tag codes for the highly acidic amino acid sequence DYKDDDDK and is located about twelve amino acids amino-terminal to the basic region. However, at least with this analysis, the tag did not appear to be a problem and from this point on no distinction will be made between the two.

\section{$\underline{\mathrm{m} 8 \mathrm{~S}^{159} \mathrm{D} \text { results in a reduced eye phenotype when crossed to scaGal4 }}$}

Males from the stock $2202 \mathrm{U}$ as well as transgenic lines expressing $\mathrm{m} 8, \mathrm{~m} 8 \mathrm{~S}^{159} \mathrm{~A}$, or $\mathrm{m} 8 \mathrm{~S}^{159} \mathrm{D}$, were crossed to females of the line scaGal4 (as described in materials and methods) which expresses Gal4 in the neural precursors of the embryo, the proneural clusters of the imaginal discs, and the morphogenetic furrow of the eye disc (Hinz et al., 1994; Nakao et al., 1996). Offspring of the cross between $2202 \mathrm{U}$ and scaGal4 exhibited wild type features (Table 5). The flies contained both macrochaete and microchaete over their bodies. The eyes of these flies contained the hexagonal array of ommatidia and ommatidial bristles (Table 5 and Figure 8). The resulting progeny of the cross between the $\mathrm{m} 8$ transgenic lines and scaGal4 exhibited a severe loss of both macrochaete and microchaete over their bodies and suffered from an approximately $50 \%$ mortality rate. Similar to wild type, the eyes of these flies exhibited the normal hexagonal array of 
ommatidia but they lacked the ommatidial bristles found in the wild type flies (Table 5 and Figure 8). This result is consistent with what has been reported in the literature (Giebel et al., 1997). $\mathrm{m} 8 \mathrm{~S}^{159} \mathrm{~A}$ appeared to be embryonic lethal as no progeny survived past this stage (Table 5). $\mathrm{m} 8 \mathrm{~S}^{159} \mathrm{D}$ resulted in a high mortality rate (Table 5), and those that did eclose exhibited a severe loss of both macrochaete and microchaete (Table 5). These progeny exhibited a unique "reduced" eye phenotype (Table 5 and Figure 8). Drosophila normally contain about 800 ommatidia whereas $m 8 \mathrm{~S}^{159} \mathrm{D}$ exhibited approximately 25 . The ommatidia that were present were misshapen and did not exhibit the classical hexagonal array. There were also no ommatidial bristles present (Figure 8). $\underline{\mathrm{m8}, \mathrm{m8S}^{159} \mathrm{~A} \text {, and } \mathrm{m8S}^{159} \mathrm{D} \text { crossed with gmrGal4 }}$

Males from the stock $2202 \mathrm{U}$ as well as transgenic lines expressing $\mathrm{m} 8, \mathrm{~m} 8 \mathrm{~S}^{159} \mathrm{~A}$, or $\mathrm{m} 8 \mathrm{~S}^{159} \mathrm{D}$, were crossed to females of the line gmrGal4 that expresses Gal4 posterior to the morphogenetic furrow. The cross between $2202 \mathrm{U}$ and gmrGal4 resulted in progeny with wild type eyes (Table 6) The only phenotype exhibited by crosses with the transgenic lines was a loss of ommatidial bristles (Table 6).

\section{$\underline{\mathrm{m8}, \mathrm{m8S}} \mathrm{S}^{159} \mathrm{~A}$, and $\mathrm{m8S} \mathrm{S}^{159} \mathrm{D}$ crossed with sevGal 4 and hGal4}

Males from the stock $2202 \mathrm{U}$ as well as transgenic lines expressing $\mathrm{m} 8, \mathrm{~m} 8 \mathrm{~S}^{159} \mathrm{~A}$, or $\mathrm{m} 8 \mathrm{~S}^{159} \mathrm{D}$, were crossed to females expressing either sevGal4 or hGal4. sevGal4 is expressed in R3, R4, R1, R6, and R7 cell while hGal4 is expressed anterior to the morphogenetic furrow (Cooper et al., 2000 ). Neither of these crosses elicited a mutant phenotype. All resulting progeny exhibited the ommatidial hexagonal array, no reduction in ommatidial number, and all contained ommatidial bristles (Tables 7 and 8 ). 


\section{$\underline{\mathrm{m}^{2} \mathrm{~S}^{159} \mathrm{D} \text { exhibits a significantly greater interaction with Atonal than } \mathrm{m8} \text { or } \mathrm{m8S}^{159} \mathrm{~A}}$}

The construct B42-Atonal was transformed into yeast strain EGYO48. This strain already contained the constructs LexA-m8, LexA-m8S ${ }^{159} \mathrm{~A}$, and LexA-m8S ${ }^{159} \mathrm{D}$ along with the LacZ-expressing plasmid pSH18-34. A liquid assay for $\beta$-galactosidase activity was performed using ONPG as substrate as described in the materials and methods. The interaction between $\mathrm{m} 8 \mathrm{~S}^{159} \mathrm{D}$ and Atonal was significantly greater than that observed between m8-Atonal or m8-S ${ }^{159} \mathrm{~A}$-Atonal (Figure 9). 


\section{Table 4: Results of Crosses with Transgenic $\mathrm{m8}$ Variants and G455.2}

\begin{tabular}{|c|c|}
\hline Transgenic Line & Bristle Phenotype \\
\hline $2202 U-w^{1118}$ & 4 scutellar bristles \\
\hline Kozak-m8 & 3 lines no scutellar bristles \\
\hline FLAG-m8 & 3 lines no scutellar bristles \\
\hline FLAG-S ${ }^{159} \mathrm{~A}$ & 3 lines no scutellar bristles \\
\hline Kozak-S ${ }^{159} D$ & 3 lines no scutellar bristles \\
\hline FLAG-S ${ }^{159} D$ & 3 lines no scutellar bristles \\
\hline
\end{tabular}

G455.2 restricts GAL4 to expression in the anlage of the scutellum (Giebel et al., 1997).

$2202 U-w^{1118}$ is the stock used for injection and functions as a control in this experiment.

Kozak refers to transgenic lines containing a Kozak sequence as described in the Materials \& Methods Section.

Flag refers to transgenic lines containing a Kozak sequence and FLAG tag as described in the Materials and Methods Section. 

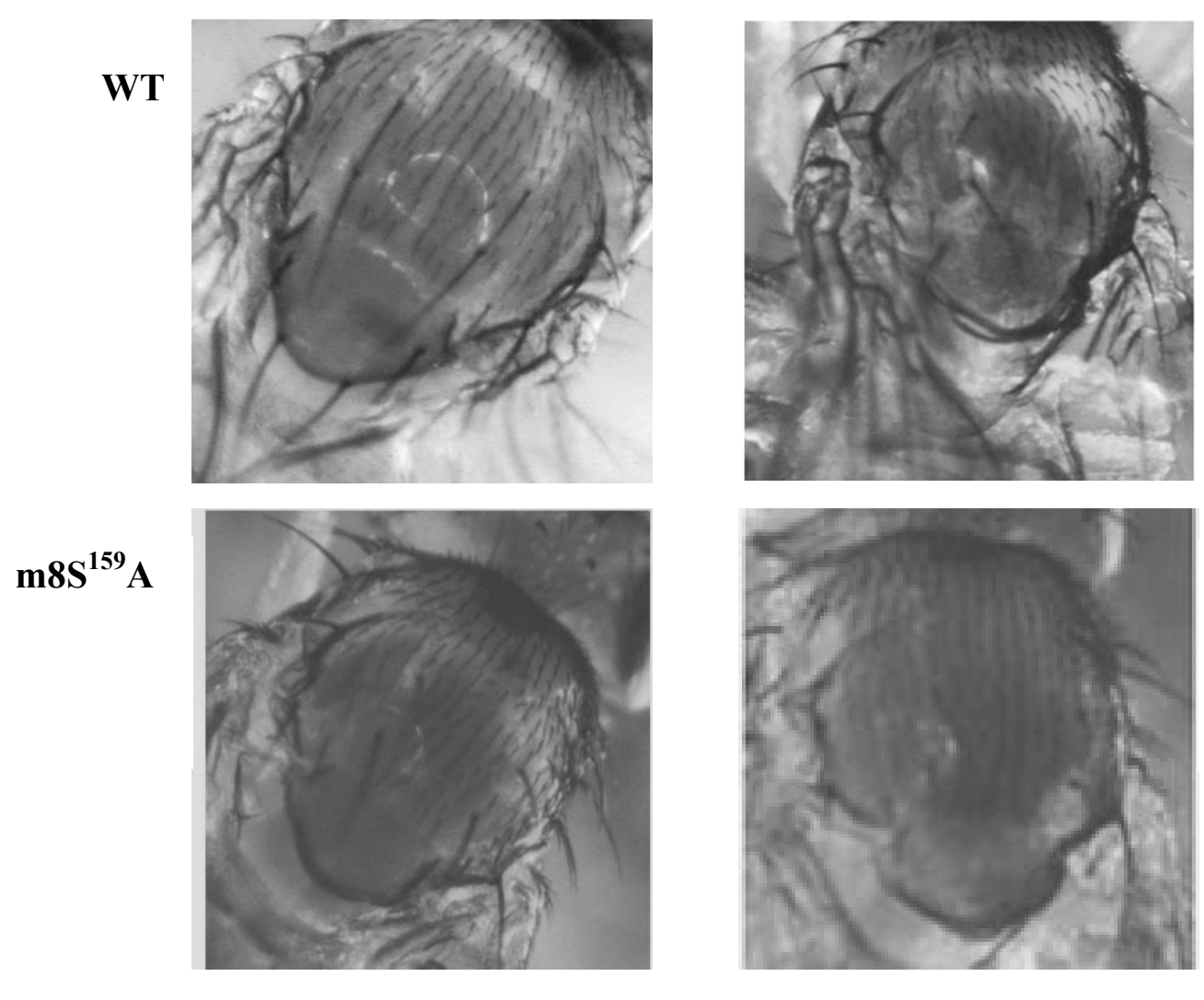

m8

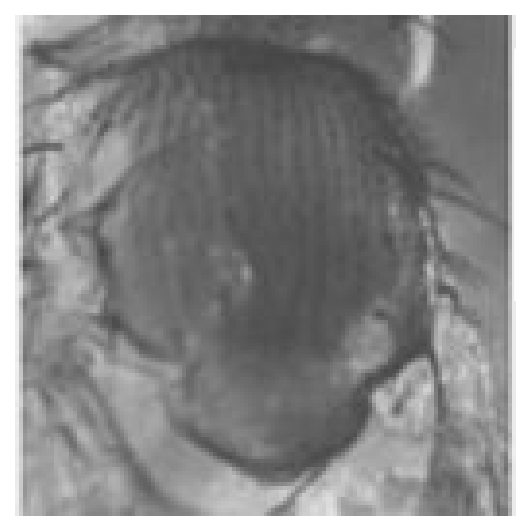

m8S ${ }^{159} D$

Figure 7: The effect of $\mathrm{m8}, \mathrm{m8S}^{159} \mathrm{~A}$, and $\mathrm{m} 8 \mathrm{~S}^{159} \mathrm{D}$ on scutellar bristle development. Male $m 8$ variants were crossed with females of the line G455.2 which restricts expression of GAL4 to the anlage of the scutellum. Wild Type (WT) flies resulted from a cross between $2202 \mathrm{U}-\mathrm{w}^{1118}$ and G455.2 and exhibit the four scutellar bristles. 
Table 5: Results of Crosses of m8 Variants with sca-Gal4

\begin{tabular}{|l|l|l|l|}
\hline $\begin{array}{l}\text { Transgenic } \\
\text { Line }\end{array}$ & Lethality & Bristle Phenotype & Eye Phenotype \\
\hline $\mathbf{2 2 0 2 U - w} \mathbf{1 1 1 8}^{1118}$ & N/A & Wild-Type & Wild-Type \\
\hline Kozak-m8 & $\begin{array}{l}\text { 3 Lines eclose; } \\
\sim 50 \% \text { die }\end{array}$ & $\begin{array}{l}\text { 3 lines lack bristles } \\
\text { over body }\end{array}$ & $\begin{array}{l}\text { No Ommatidial } \\
\text { Bristles }\end{array}$ \\
\hline FLAG-m8 & $\begin{array}{l}\text { 3 lines eclose; } \\
\sim 50 \% \text { die }\end{array}$ & $\begin{array}{l}\text { 3 lines lack bristles } \\
\text { over body }\end{array}$ & $\begin{array}{l}\text { No Ommatidial } \\
\text { Bristles }\end{array}$ \\
\hline FLAG-S ${ }^{159}$ A & $\begin{array}{l}\text { 3 lines } \\
\text { embryonic }\end{array}$ & N/A & N/A \\
\hline Kozak-S ${ }^{159}$ D & $\begin{array}{l}\text { 3 lines pupal } \\
\text { (few eclose) }\end{array}$ & $\begin{array}{l}\text { 3 lines lack bristles } \\
\text { over body }\end{array}$ & 3 lines reduced \\
\hline FLAG-S ${ }^{159}$ D & $\begin{array}{l}\text { 3 lines pupal } \\
\text { (few eclose) }\end{array}$ & $\begin{array}{l}\text { 3 lines lack bristles } \\
\text { over body }\end{array}$ & 3 lines reduced \\
\hline
\end{tabular}

sca-gal4 expresses gal4 in neuroectoderm and proneural clusters of the imaginal discs and the morphogenetic furrow of the eye disc (Hinz et al., 1994; Nakao et al., 1996).

$2202 \mathrm{U}$ is the stock used for injection and therefor represents a control used in this experiment.

Kozak refers to transgenic lines containing a Kozak sequence as described in the Materials \& Methods Section.

Flag refers to transgenic lines containing a Kozak sequence and FLAG tag as described in the Materials \& Methods Section. 

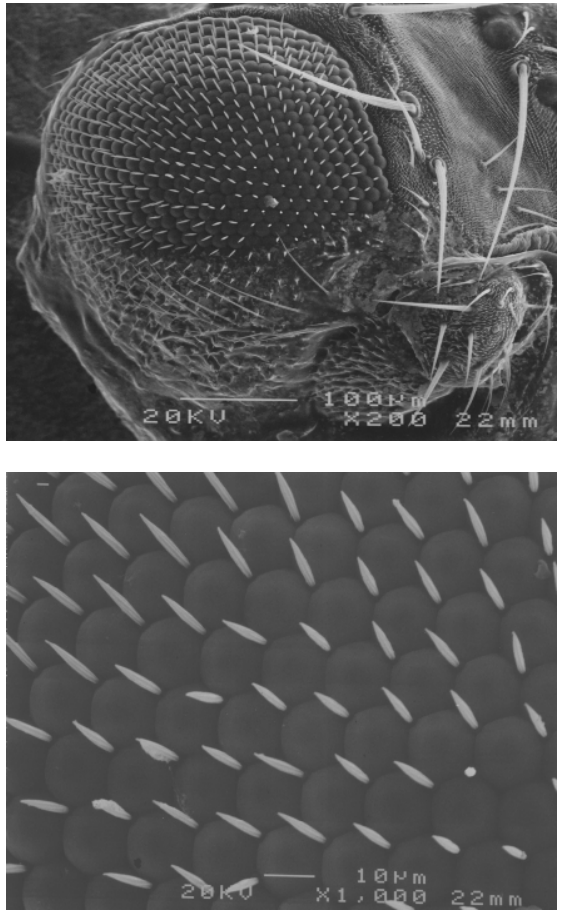

$W T$
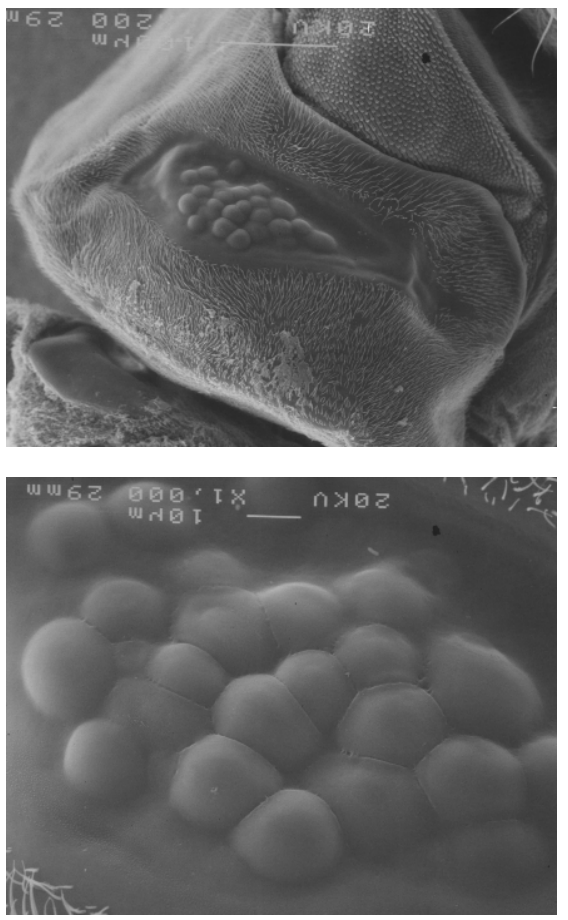

$\mathrm{m8S}^{159} \mathrm{D}$
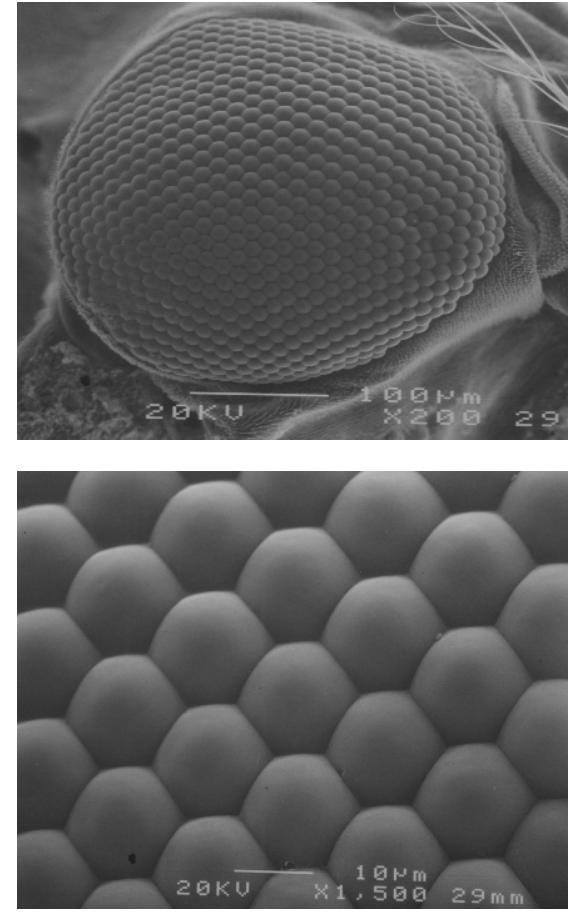

m8

Figure 8. Electron microscopy of eye phenotypes. Male $2202 \mathrm{U}-\mathrm{w}^{1118}$ (WT), m8, and $\mathrm{m} \mathrm{S}^{159} \mathrm{D}$ were crossed to female sca-GAL4. "WT" eyes exhibit the interommatidial bristles and hexagonal array of ommatidia. M8 exhibits the hexagonal array but no interommatidial bristles. $\mathrm{m8S}^{159} \mathrm{D}$ eyes no longer exhibit the hexagonal array, there are no interommatidial bristles, and the number of ommatidia is reduced from 800 to approximately 25 . 
Table 6: Results of Crosses of m8 Variants with gmrGal4

\begin{tabular}{|c|c|}
\hline Transgenic Line & Eye Phenotype \\
\hline $2202 U-w^{1118}$ & Wild Type \\
\hline Kozak-m8 & 3 Lines Loss Of Ommatidial Bristles \\
\hline FLAG-m8 & 3 Lines Loss Of Ommatidial Bristles \\
\hline FLAG-S ${ }^{159}$ A & 3 Lines Loss Of Ommatidial Bristles \\
\hline Kozak-S ${ }^{159} D$ & 3 Lines Loss Of Ommatidial Bristles \\
\hline FLAG-S ${ }^{159} D$ & 3 Lines Loss Of Ommatidial Bristles \\
\hline
\end{tabular}

gmrgal4 expresses GAL4 posterior to the morphogenetic furrow (Flybase, A Database of the Drosophila Genome: http://flybase.bio.indiana.edu/)

$2202 \mathrm{U}-\mathrm{w}^{1118}$ is the stock used for injection and serves as a control in this experiment.

Kozak refers to transgenic lines containing a Kozak sequence as described in the Materials \& Methods Section.

Flag refers to transgenic lines containing a Kozak sequence and FLAG tag as described in the Materials \& Methods Section. 
Table 7: Results of Crosses of m8 Variants with hGal4

\begin{tabular}{|c|c|}
\hline Transgenic Line & Eye Phenotype \\
\hline $2202 U-w^{1118}$ & Wild Type \\
\hline Kozak-m8 & Wild Type \\
\hline FLAG-m8 & Wild Type \\
\hline FLAG-S ${ }^{159} \mathrm{~A}$ & Wild Type \\
\hline Kozak-S ${ }^{159}$ D & Wild Type \\
\hline FLAG-S ${ }^{159} D$ & Wild Type \\
\hline
\end{tabular}

hgal4 expresses GAL4 anterior to the morphogenetic furrow (Flybase, A Database of the Drosophila Genome: http://flybase.bio.indiana.edu/)

$2202 \mathrm{U}-\mathrm{w}^{1118}$ is the stock used for injection and serves as a control in this experiment.

Kozak refers to transgenic lines containing a Kozak sequence as described in the Materials \& Methods Section.

Flag refers to transgenic lines containing a Kozak sequence and FLAG tag as described in the Materials \& Methods Section. 


\section{Table 8: Results of Crosses of $\mathrm{m8}$ Variants with sevGal4}

\begin{tabular}{|c|c|}
\hline Transgenic Line & Eye Phenotype \\
\hline $2202 U-w^{1118}$ & Wild Type \\
\hline Kozak-m8 & Wild Type \\
\hline FLAG-m8 & Wild Type \\
\hline FLAG-S ${ }^{159} \mathbf{A}$ & Wild Type \\
\hline Kozak-S ${ }^{159} D$ & Wild Type \\
\hline FLAG-S ${ }^{159} D$ & Wild Type \\
\hline
\end{tabular}

sevgal4 expresses GAL4 in the R3, R4, R1, R6, and R7 photoreceptor cells (Cooper et al., 2000).

$2202 \mathrm{U}-\mathrm{w}^{1118}$ is the stock used for injection and serves as a control in this experiment.

Kozak refers to transgenic lines containing a Kozak sequence as described in the Materials \& Methods Section.

Flag refers to transgenic lines containing a Kozak sequence and FLAG tag as described in the Materials \& Methods Section. 


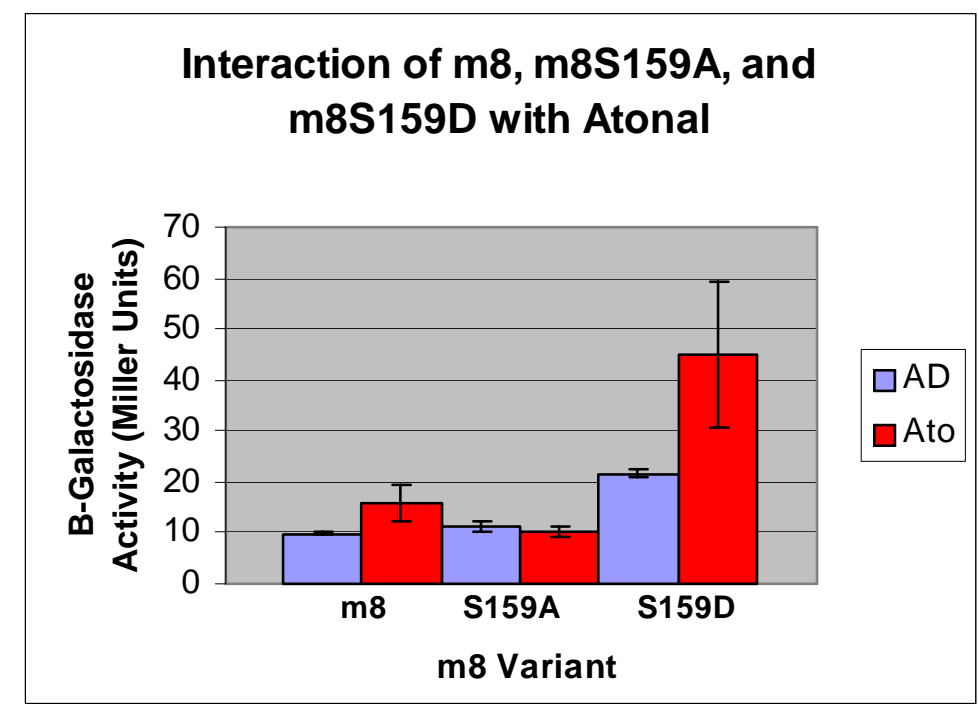

Figure 9. Yeast two-hybrid interaction analysis of $\mathrm{m8}, \mathrm{m8S}^{159} \mathrm{~A}$, and $\underline{\mathrm{m8S}}{ }^{159} \mathrm{D}$ with Atonal. The plasmids LexA-m8, $\operatorname{LexA}-\mathrm{m8S}^{159} \mathrm{~A}$, and LexA$\mathrm{m8S}^{159} \mathrm{D}$ were transformed into the yeast strain EGYO48 (already harboring the $E$. coli Lac $\mathrm{Z}$ expression plasmid) along with the $\mathrm{B42}$ activation domain (AD) or the activation domain fused to Atonal (Ato). $\beta$ galactosidase activity is expressed in Miller Units and was determined by liquid assay as described in the materials and methods. Three independent colonies were used for each combination and run in triplicate. The graph represents the mean for a sample and the "error bars" the standard deviation. 


\section{Discussion:}

The Drosophila peripheral nervous system is composed of four types of sensory structures, two of which are relevant to this work: bristles, which function as an external sensory organ; and the photoreceptors which comprise each ommatidium (Jarman et al., 1995).

The Notch pathway as it pertains to neural development was discussed in the introduction of this thesis and therefore will not be repeated extensively here. Briefly, in order for a bristle to develop, the proneural genes of the achaete-scute complex are expressed in the proneural clusters (Jarman et al., 1995). Lateral inhibition then restricts one cell to the sensory organ precursor (SOP) fate (Jarman et al., 1995). Surrounding cells, through the activation of the Notch pathway and subsequently members of the E(spl)-C, adopt an epidermal fate (Jarman et al., 1995). The SOP will then undergo two cellular divisions (Wolpert et al., 2002). The first division produces two cells (Wolpert et al., 2002). One cell will divide to form the hair cell and socket cell; the other cell will divide to form the neuron and sheath cell (Wolpert et al., 2002). Therefore, the bristle provides a visible marker for the presence or absence of SOP formation.

The bristles found on the adult fly are termed macrochaete (the larger bristles) and microchaete (the smaller bristles). The scutellum of wild-type flies typically contains four macrochaete. Previous studies of Bernd Giebel and Jose A. Campos-Ortega (1997) illustrated that when flies containing the $\mathrm{m} 8$ transgene were crossed to the Gal4 expressing line G455.2 (which limits the expression of Gal4 solely to the anlage of the scutellum), the resulting progeny were devoid of scutellar bristles, consistent with the 
function of this protein as a repressor of neurogenesis. During the current study, flies containing the $\mathrm{m} 8$ variants were crossed to the Gal4 expressing line G455.2.

The progeny of the above cross were devoid of scutellar bristles. The results obtained for $\mathrm{m} 8$ were consistent with those reported in the literature (Giebel et al., 1997). The results of this analysis further indicate the phosphorylation state of $\mathrm{m} 8$ is not critical for the functional repression of neurogenesis (at least for scutellar bristle development) since the ectopic expression of $\mathrm{m} 8 \mathrm{~S}^{159} \mathrm{~A}$, which should never be phosphorylated, and $\mathrm{m} 8 \mathrm{~S}^{159} \mathrm{D}$, which mimics constitutive phosphorylation, as well as wild-type $\mathrm{m} 8$, produced comparable results.

A driver referred to as scaGal4 was next utilized. scaGal4 expresses Gal4 in the neural precursors of the embryo, the proneural clusters of the imaginal discs, and the morphogenetic furrow of the eye disc (Hinz et al., 1994; Nakao et al., 1996). In the case of $\mathrm{m} 8$, it can be seen that most of the macro- and microchaete were missing over the majority of the fly's body. It was also noted that while a number of flies eclosed, there was about a $50 \%$ mortality rate. These results are consistent with those previously observed (Giebel et al., 1997). In the case of $\mathrm{m} 8 \mathrm{~S}^{159} \mathrm{~A}$, embryonic lethality appeared to be the result as embryos were present on the surface of the food but no larvae, pupae, or adults were ever seen. $\mathrm{m} 8 \mathrm{~S}^{159} \mathrm{D}$ resulted in a severe loss of both macrochaete and microchaete and while the progeny survived to the pupal stage, very few flies actually eclosed. While this data seems to indicate that the phosphorylation of m 8 may increase its antineurogenic function, this possibility was not explored any further for this study. In the case of $\mathrm{S}^{159} \mathrm{~A}$, it appears that the lack of $\mathrm{m} 8$ phosphorylation by $\mathrm{CK} 2$ played a role in the deaths of the embryos while constitutive phosphorylation allowed the embryos to 
proceed through this stage. What affect $\mathrm{m} 8 \mathrm{~S}^{159} \mathrm{~A}$ has on development (i.e., whether an increase in neurogenesis or antineurogenic effects) remains unknown at this time as this result was not explored any further.

What was of particular interest in the $\mathrm{m} 8 \mathrm{~S}^{159} \mathrm{D}$ flies was the presence of a "reduced" eye phenotype. As illustrated in the electron micrographs of Figure 8, m8 resulted in a loss of ommatidial bristles but the structure of the ommatidia as well as the number of ommatidia appeared to be the same as that for wild-type flies. In the case of $\mathrm{m} 8 \mathrm{~S}^{159} \mathrm{D}$, not only was there a loss of ommatidial bristles, but a great reduction in the number of ommatidia from about 800 in the wild-type fly to approximately twenty-five in the $\mathrm{m} 8 \mathrm{~S}^{159} \mathrm{D}$ variant.

In the compound eye of the wild type fly, each ommatidiuim consists of eight photoreceptors, four cone cells that secrete the lens, and two primary pigment cells (Freeman 1997). There are also six secondary and three tertiary pigment cells that are shared with adjacent ommatidia (Freeman 1997). The ommatidia are arranged in a regular hexagonal array with a bristle projecting from the surface of the eye at the intersection where three adjacent ommatidia meet (Bodenstein et al., 1965; Tomlinson 1988; Freeman 1997). Eye development in Drosophila begins during the third larval instar in the eye imaginal disc (Wolpert et al., 2002). The eye imaginal disc consists of a single layer of epithelium (Wolpert et al., 2002). Formation of the ommatidia is initiated in a groove referred to as the morphogenetic furrow (MF) (Wolpert et al., 2002). The MF moves from the posterior of the disc towards the anterior (Wolpert et al., 2002). The cells in front of the disc continue to proliferate but arrest in the $\mathrm{G}_{1}$ phase of the cell cycle as the MF nears (Freeman 1997). Within the MF there is a precluster of cells that will develop 
into the first five photoreceptors (Ready et al., 1976; Freeman 1997). The cells that form the last three photoreceptors and the accessory cells do not develop until after the MF has passed (Ready et al., 1976; Freeman 1997). The eight photoreceptors are invariant in their positions within the ommatidia (Freeman 1997). The first photoreceptor to differentiate is R8 (Wolpert et al., 2002). The next two are R2 and R5 followed by R3 and R4 (Wolpert et al., 2002). Finally, R1 and R6 differentiate with R7 being the last to do so (Wolpert et al., 2002). After this formation, the four cone cells develop and during the pupal stage the primary pigment cells followed by the secondary and tertiary pigment cells develop (Cagan et al., 1989).

While bristle development requires genes of the achaete-scute complex, eye development requires the bHLH proneural protein atonal (Jarman et al., 1995). Atonal is required for the formation of the R8 photoreceptor (Jarman et al., 1995). The R8 photoreceptor then initiates a signal cascade the functions to recruit a cluster of 20 cells to form an ommatidium (Wolpert et al., 2002). The Notch pathway is initially required to maintain atonal at high levels, a process termed "proneural enhancement" and the opposite of its function during bristle development (Frankfort et al., 2002). Later, however, Notch functions through the process of lateral inhibition to activate members of the $\mathrm{E}$ (spl)-C (including $\mathrm{m} 8$ ) which then functions to repress atonal so that only one R8 cell develops per ommatidium (Frankfort et al., 2002).

Why focus on atonal expression? Research conducted by Anja C. Nagel and Anette Preiss had previously illustrated that a mutation in the E(spl) locus [termed $\left.\mathrm{E}(\mathrm{spl})^{\mathrm{D}}\right]$ which results in the production of a truncated $\mathrm{m} 8$ protein lacking the region carboxyl terminal to the orange domain $\}$, when expressed in combination with the $\mathrm{N}^{\mathrm{spl}}$ 
allele of Notch \{which itself results in a slightly reduced eye phenotype\}, resulted in a reduced eye phenotype as well (Nagel et al., 1999). One difference between this study and that of Nagel and Preiss is that $\mathrm{m}^{15} \mathrm{~S}^{159} \mathrm{D}$ produced the eye phenotype with only one copy of the transgene and in a Notch wild type background. One possibility is that since $\mathrm{E}(\mathrm{spl})^{\mathrm{D}}$ lacks the region carboxyl-terminal to the orange domain, the protein can no longer interact with Groucho (Giebel et al., 1997; Karandikar et al., 2004). Since this critical interaction is no longer possible, $\mathrm{E}(\mathrm{spl})^{\mathrm{D}}$ may require the Notch $^{\mathrm{spl}}$ background in order to produce a visible phenotype (Karandikar et al., 2004). It should also be noted that the levels of Atonal in Notch ${ }^{\text {spl }}$ mutants are lower than those found in flies wild type for Notch which could also contribute to the phenotype obtained in the studies of Nagel and Preiss (Nagel et al., 1999; Karandikar et al., 2004).

Nagel and Preiss also found (through the use of the yeast two-hybrid system) that the truncated $\mathrm{m} 8$ interacted strongly with the proneural basic helix-loop-helix protein atonal (Nagel et al., 1999). This interaction was significantly greater than that observed between wild type $\mathrm{m} 8$ and Atonal (Nagel et al., 1999). In light of this information, we decided to explore the interaction of $\mathrm{m}^{8} \mathrm{~S}^{159} \mathrm{D}$ with atonal as one possible mechanism for the reduced eye phenotype observed in this study.

Yeast containing LexA-m8, LexA-m8S ${ }^{159} \mathrm{~A}$, and LexA-m8S ${ }^{159} \mathrm{D}$ were transformed with B42-Atonal. The results indicated a significantly greater interaction between Atonal and $\mathrm{m} 8 \mathrm{~S}^{159} \mathrm{D}$ than with either of the other variants tested. This result does open up the possibility that the eye phenotype observed in this study is a result of the increased interaction between Atonal and phosphorylated m8. 
Three other Gal4 lines which express Gal4 in the eye discs were also used for this study. These included gmrGal4 which expresses Gal4 posterior to the morphogenetic furrow, hGal4 which expresses Gal4 anterior to the morphogenetic furrow, and sevGal4 which expresses Gal4 in the R3, R4, R1, R6, and R7 photoreceptor cells (Cooper et al., 2000). While gmrGal4 resulted in the loss of ommatidial bristles with all $\mathrm{m} 8$ variants, none of the additional Gal4 drivers tested produced a reduced eye phenotype. These results seem to further support the data indicating that the phosphorylation of $\mathrm{m} 8$ functions within the morphogenetic furrow perhaps by antagonizing the proneural protein, Atonal.

The results presented in this chapter illustrate a role for the phosphorylation of the $\mathrm{E}(\mathrm{spl})$ protein $\mathrm{m} 8$ by protein kinase $\mathrm{CK} 2$. A reduced eye phenotype was obtained when flies expressing the transgene $\mathrm{m} 8 \mathrm{~S}^{159} \mathrm{D}$ were crossed to the Gal4 expressing line scaGal4. Yeast two-hybrid data indicated a significantly greater interaction between the proneural protein, Atonal, and $\mathrm{m} 8 \mathrm{~S}^{159} \mathrm{D}$ as compared to $\mathrm{m} 8$ or $\mathrm{m} 8 \mathrm{~S}^{159} \mathrm{~A}$. An increase in lethality was also noted in crosses of $m 8 \mathrm{~S}^{159} \mathrm{D}$ and scaGal4 as compared to $\mathrm{m} 8$, although this has not been explored any further. The phosphorylation state of $\mathrm{m} 8$ did not appear to play a significant role in the antineurogenic affects of $\mathrm{m} 8$ on scutellar bristle development as all variants resulted in a loss of macrochaete from this structure. 


\section{$\underline{\text { Summary }}$}

The hypotheses stated in the introduction are partially supported by the data obtained in these studies. Chapter 1 presented data supporting the finding that $\mathrm{m} 8$ was a substrate of protein kinase CK2. This was done through phosphorylation reactions, yeast two-hybrid analysis, and the mapping of the phosphorylation site through site directed mutagenesis. Also presented in Chapter 1 were some possible functions for the phosphorylation of this protein. These possibilities were derived from previous knowledge of PEST domains, phosphorylation by CK2 on other proteins and what the affects of these phosphorylations were. Based on this data, it seemed the best hypothesis as to the function of phosphorylation by $\mathrm{CK} 2$ on $\mathrm{m} 8$ was that it would increase the degradation rate of the protein and therefore the turnover rate. This was the first indication that $\mathrm{E}(\mathrm{spl})$ proteins could potentially be regulated by phosphorylation. This was also the first implication for CK2 in the process of neurogenesis.

The use of the Gal4-UAS system in transgenic flies elucidated a new role for phosphorylation of $\mathrm{m} 8$ by $\mathrm{CK} 2$ as indicated by the reduced eye phenotype (although the initial hypothesis speculated a role in bristle development) and the increased interaction between phosphorylated $\mathrm{m} 8$ (as mimicked by $\mathrm{m} 8 \mathrm{~S}^{159} \mathrm{D}$ ) and the proneural protein Atonal. This was not the mechanism of first choice when speculating as to the potential function of this phosphorylation. It was originally thought that since the CK2 site was found within a PEST domain, that the likely role of phosphorylation was to increase the turnover rate of the protein. While the results obtained in this study indicate a physiologically important role for phosphorylation of $\mathrm{m} 8$ by $\mathrm{CK} 2$, it is also possible that some other mechanism functions (i.e., other than protein-protein interactions) which 
resulted in embryonic lethality in the case of $\mathrm{m} 8 \mathrm{~S}^{159} \mathrm{~A}$ or the increased lethality seen in $\mathrm{m} 8 \mathrm{~S}^{159} \mathrm{D}$ when crossed with scaGal4. While the goal of this work in finding a new physiologically significant substrate of CK2 was achieved, further analysis is needed to confirm that the observed yeast two-hybrid interaction between $\mathrm{m} 8 \mathrm{~S}^{159} \mathrm{D}$ and Atonal is the actual mechanism that produced the eye phenotype observed in Drosophila. 


\section{$\underline{\text { References }}$}

Alifragis, P., Poortinga, G., Parkhurst, S.M., and Delidakis, C. (1997) A network of interacting transcriptional regulators involved in Drosophila neural fate specification revealed by the yeast two-hybrid system. Proc. Natl. Acad. Sci. USA 94, 13099-13104

Allende, J.E., and Allende, C.C. (1995) Protein kinase CK2: an enzyme with multiple substrates and a puzzling regulation. FASEB J. 9, 313-323

Artavanis-Tsakonas, S., Rand, M.D. and Lake, R.J. (1999) Notch signaling: cell fate control and signal integration in development. Science 284, 770-776

Artavanis-Tsakonas, S., Matsuno, K., and Fortini, M.E. (1995) Notch Signaling. Science 268, 225-232

Atchley, W., and Fitch, W. (1997) A natural classification of the basic helix-loop-helix class of transcription factors. Proc. Natl. Acad. Sci. USA 94, 5172-5176

Ausubel, F.M., Brent, R., Kingston, R.E., Moore, D.D., Seidman, J.G., Smith, G.A. and Struhl, K. (1995) Current Protocols in Molecular Biology (Wiley, New York)

Bate, M., Rushton, E., and Frasch, M. (1993) A dual requirement for neurogenic genes in Drosophila myogenesis. Development Suppl. 149-161

Bergholtz, S., Andersen, T.O., Andersson, K.B., Borreback, J., Luexcher, B., and Gabrielsen, S. (2001) The highly conserved DNA-binding domains of A-, B-, and c-Myb differ with respect to DNA-binding, phosphorylation and redox properties. Nucleic Acids Res. 29, 3546-3456

Bidwai, A.P. (2000) Structure and function of casein kinase II. Recent Res. Devel. Mol. Cell. Biol. 1, 51-82

Bidwai, A.P., Zhao, W., and Glover, C.V.C. (1999) A Gene Located at 56F1-2 in Drosophila melanogaster Encodes a Novel Metazoan $\beta$-like Subunit. Mol. Cell Biol. Res. Comm. 1, 21-28

Bidwai, A.P., Reed, J.C., and Glover, C.V.C. (1994) Casein kinase II of Saccharomyces cerevisiae contains two distinct regulatory subunits, $\beta$ and $\beta$ '. Arch. Biochem. Biophys. 309, 348-355

Bidwai, A.P., Reed, J.C., and Glover, C.V.C. (1993) Phosphorylation of Calmodulin by the Catalytic Subunit of Casein Kinase II is Inhibited by the Regulatory Subunit. Arch. Biochem. Biophys. 300, 265-270

Bidwai, A.P., Hanna, D.E., and Glover, C.V.C. (1992) Purification and characterization of casein kinase II (CKII) from delta cka1 delta cka2 Saccharomyces cerevisiae rescued 
by Drosophila CKII subunits. The free catalytic subunit of casein kinase II is not toxic in vivo.J. Biol. Chem. 267, 18790-18796

Bodenstein, D., Cooper, K.W., Ferris, G.F., Miller, A., Poulson, D.F., Sonnenblick, B.P., and Spencer, W.P. (1965) The Sense Organs. In M. Demerec (Ed.), Biology of Drosophila (pp. 498-507). Cold Spring Harbor, NY: Hafner

Boldyreff, B., Meggio, F., Pinna, L.A., and Issinger, O.-G. (1993) Reconstitution of normal and hyperactivated forms of casein kinase- 2 by variably mutated $\beta$-subunits. Biochemistry 32, 12672-12677

Boldyrell, B., Pontek, K., Schmidt-Spanial,I., and Issinger, O.G. (1991) The beta subunit of casein kinase II: cloning of cDNAs from murine and porcine origin and expression of the porcine sequence as a fusion protein. Biochim. Biophys. Acta 1088, 439-441

Bourbon, J.-M., Martin-Blanco, E., Rosen, D., and Kornberg, T.B. (1995)

Phosphorylation of the Drosophila engrailed protein at a site outside its homeodomain enhances DNA binding. J. Biol. Chem. 270,11130-11139

Brand, A.H., and Perrimon, N. (1993) Targeted gene expression as a means of altering cell fates and generating dominant phenotypes. Development 118, 401-415

Burnett, G. and Kennedy, E.P. (1954) The Enzymatic Phosphorylation Of Proteins. J. Biol. Chem. 211, 969-980

Cabrera, C.V. (1990) Lateral inhibition and cell fate during neurogenesis in Drosophila: the interactions between scute, Notch and Delta. Development 109, 733-742

Cagan, R.L., and Ready, D.L. (1989) Notch is required for successive decisions in the developing Drosophila retina. Genes Dev. 3, 1099-1112

Canton, D.A., Zhang, C. and Litchfield, D.W. (2001) Assembly of protein kinase CK2: investigation of complex formation between catalytic and regulatory subunits using a zinc-finger-deficient mutant of CK2 $\beta$. Biochem. J. 358, 87-94

Carroll, D., and Marshak, D.R. (1989) Serum-stimulated cell growth causes oscillations in casein kinase II activity. J Biol Chem 264, 7345-73488.

Castro, B., Barolo, S., Bailey, A.M., and Posakony, J.W. (2005) Lateral inhibition in proneural clusters: cis-regulatory logic and default repression by Suppressor of Hairless. Development 132, 3333-3344

Chan, Y.M., and Jan, Y.N. (1998) Roles for Proteolysis and Trafficking in Notch Maturation and Signal Transduction. Cell 94, 423-426 
Chantalat, L., Leroy, D., Filhol, O., Nueda, A., Benitez, M.J., Chambaz, E.M., Cochet, C. and Dideberg, O. (1999) Crystal structure of the human protein kinase CK2 regulatory subunit reveals its zinc finger-mediated dimerization. Embo. J. 18, 2930-2940

Chasan, R. and Anderson, K.V. (1993) Maternal control of dorsal-ventral polarity and pattern in the embryo. In The development of Drosophila melanogaster, (ed. M. Bate and A. Martinez-Arias), pp.387-432. Cold Spring Harbor Laboratory Press, Cold Spring Harbor, NY.

Chen, G. and Courey, AJ. (2000) Groucho/TLE family proteins and transcriptional repression. Gene 249, 1-16

Collinge, M.A., and Walker, J.C. (1994) Isolation of an Arabidopsis thaliana casein kinase II $\beta$ subunit by complementation in Saccharomycrs cerevisiae. Plant Mol. Biol. 25, 649-658

Cooper, M.T.D., and Bray, S.J. (2000) R7 photoreceptor specification requires Notch activity. Curr. Biol. 10, 1507-1510

Corbett, A.H., Devore, R.F., and Osheroff, N. (1992) Effect of casein kinase II mediated phosphorylation on the catalytic cycle of topoisomerase II. J. Biol. Chem. 267, 2051320518

Corbin, V., Michelson, A.M., Abmayr, S.M., Neel, V., Alcamo, E., Maniatis, T., and Young, M.W. (1991) A role for the Drosophila neurogenic genes in mesoderm differentiation. Cell 67, 311-323

Cubas, P., de Celis, J.F., Campuzano, S., and Modolell, J. (1991) Proneural clusters of achaete-scute expression and the generation of sensory organs in the Drosophila imaginal wing disc. Genes Dev. 5, 996-1008

de Celis, J., de Celis, J., Ligoxygakis, P., Preiss, A., Delidakis, C. and Bray, S. (1996) Functional relationships between Notch, $\mathrm{Su}(\mathrm{H})$ and the bHLH genes of the $\mathrm{E}(\mathrm{spl})$ complex: the $\mathrm{E}(\mathrm{spl})$ genes mediate only a subset of Notch activity during imaginal development. Development 122, 2719-2728

de Celis, J.F., and Garcia-Bellido, A. (1994) Roles of the Notch gene in Drosophila wing morphogenesis. Mech Dev 46, 109-22.

Delidakis, C., Preiss, A., Hartley, D.A., and Artavanis-Tsakonas, S. (1991) Two genetically and molecularly distinct functions involved in early neurogenesis reside within the Enhancer of split locus of Drosophila melanogaster. Genetics 129, 803-823

Delidakis, C., and Artavanis-Tsakonas, S. (1992) The Enhancer of split [E(spl)] locus of Drosophila encodes seven independent helix-loop-helix proteins. Proc. Nat. Acad. Sci.

USA 89, 8731-8735 
Doe, C.Q. and Goodman, C.S. (1985) Early events in insect neurogenesis. II. The role of cell interactions and cell lineage in the determination of neuronal precursor cells. Dev. Biol. 111, 206-219

Estojak, J., Brent, R., andGolemis, E.A. (1995) Correlation of two-hybrid affinity data with in vitro measurements. Mol. Cell. Biol. 15, 5820-5829

Feilotter, H.E., Hannon, G.J., Ruddell, C.J., and Beach, D. (1994) Construction of an improved host strain for two hybrid screening. Nucleic Acids Res. 22, 1502-1503

Fisher, A. and Caudy, M. (1998) The function of hairy-related bHLH repressor proteins in cell fate decisions. BioEssays 20, 298-306

Fisher, S.L., Ohshako, S. and Caudy, M. (1996) The WRPW motif of the Hairy-related basic helix-loop-helix repressor proteins acts as a 4-amino-acid transcription repression and protein-protein interaction domain. Mol. Cell. Biol. 16, 2670-2677

Flybase, A Database of the Drosophila Genome: http://flybase.bio.indiana.edu/

Frankfort, B.J., and Mardon, G. (2002) R8 development in the Drosophila eye: a paradigm for neural selection and differentiation. Development 129, 1295-1306

Freeman, M. (1997) Cell determination strategies in the Drosophila eye. Development 124, 261-270

Gatica, M., Hinrichs, M.V., Jedlicki, A., Allende, C.C. and Allende, J.E. (1993) Effect of metal ions on the ativity of casein kinase II from Xenopus laevis. FEBS Lett. 315, 173 177

Giebel, B., and Campos-Ortega, J.A. (1997) Functional dissection of the Drosophila Enhancer of split protein, a suppressor of neurogenesis. Proc. Natl. Acad. Sci. USA 94, 6250-6254

Gietz, R.D., Graham, K.C. and Litchfield, D.W. (1995) Interactions between the subunits of casein kinase II. J. Biol. Chem. 270, 13017-13021

Giagtzoglou, N., Alifragis, P. Koumbanakis, K.A. and Delidakis, C. (2003) Two modes of recruitment of $\mathrm{E}(\mathrm{spl})$ repressors onto target genes. Development 130, 259-270

Gigliani, F., Longo, F., Gaddini, L., and Battaglia, P.A. (1996) Interactions among the bHLH domains of the proteins encoded by the Enhancer of split and achaete-scute gene complexes of Drosophila. Mol. Gen. Genet. 251, 628-634

Glover III, C.V. (1998) On the physiological role of casein kinase II in Saccharomyces cerevisiae. Prog. Nucleic Acid Res. Mol. Biol. 59, 95-133 
Glover, C. V. C., Shelton, E.R., and Brutlag, D.L. (1983) Purification and Characterization of a Type II Casein Kinase from Drosophila melanogaster. J. Biol. Chem. 258, 3258-3265

Glover, C.V.C. (1986) A filamentous form of Drosophila casein kinase II. J. Biol. Chem. 261, 14349-14354

Graham, K.C. and Litchfield, D.W. (2000) The regulatory beta-subunit of protein kinase CK2 mediates formation of tetrameric CK2 complexes. J. Biol. Chem. 275, 5003-5010

Greenwald, I. (1998) LIN-12/Notch signalling: lessons from worms and flies. Genes Dev. 12, 1751-1762

Hanna, D.E., Rethinaswamy, A., Glover, C.V. (1995) Casein kinase II is required for cell cycle progression during G1 and G2/M in Saccharomyces cerevisiae. J. Biol. Chem. 270, 25905-25914

Hartenstein, V., and Posakony, J.W. (1990) A dual function of the Notch gene in Drosophila sensillum development. Dev. Biol. 142, 13-30

Hartley, D.A., Preiss, A., and Artavanis-Tsakonas, S. (1988) A deduced gene product from the Drosophila neurogenic locus Enhancer of split shows homology to mammalian G-protein $\beta$ subunit. Cell 55, 785-795

Hathaway, G.M., Lubben, T.H., and Traugh, J.A. (1980) Inhibition of Casein Kinase II by Heparin. J. Biol. Chem. 255, 8038-8041

Heller-Harrisson, R.A., Meisner, H. and Czech, M.P. (1989) Cloning and characterization of a cDNA encoding the $\beta$ subunit of human casein kinase II. Biochemistry 28, 90539058

Heriche, J.K., Lebrin, F., Rabilloud, T., Leroy, D., Chambaz, E.M. and Goldberg, Y. (1997) Regulation of protein phosphatase 2A by direct interaction with casein kinase 2 . Science 276, 952-955

Hinz, U., Giebel, B., and Campos-Ortega, J.A. (1994) The basic-helix-loop-helix domain of Drosophila lethal of scute protein is sufficient for proneural function and activates neurogenic genes. Cell 76, 77-87

$\mathrm{Hu}$, E., and Rubin, C.S. (1990) Expression of wild-type and mutated forms of the catalytic $(\alpha)$ subunit of Caenorhabditis elegans casein kinase II in Escherichia coli. J. Biol. Chem. 265, 20609-20615

Hunter, T. and Plowman, G.D. (1997) The protein kinases of budding yeast: six score and more. Trends Biochem. Sci. 22, 18-22 
Issinger, O.G., Benne, R., Hershey, J.W.B., and Traut, R.R. (1976) Phosphorylation in Vitro of Eukaryotic Initiation Factors IF-E2 and IF-E3 by Protein Kinases. J. Biol. Chem. 251, 6471-6474

Jaffe, L., Ryoo, H.D., and Mann, R.S. (1997) A role for phosphorylation by casein kinase II in modulating Antennapedia activity in Drosophila. Genes \& Dev. 11, 1327-1340

Jan, Y.N., and Jan. L.Y. (1993) HLH proteins, fly neurogenesis, and vertebrate myogenesis. Cell 75, 827-830

Jarman, A.P., Sun, Y., Jan, L.Y., and Jan, Y.N. (1995) Role of the proneural gene, atonal, in formation of Drosophila chordotonal organs and photoreceptors. Development 121, 2019-2030

Jauch, E., Melzig, J., Brkulj, M. and Raabe, T. (2002) In vivo functional analysis of Drosophila protein kinase casein kinase 2 (CK2) $\beta$-subunit. Gene

Jennings, B.H., Tyler, D.M. and Bray, S.J. (1999) Target specificities of Drosophila enhancer of split basic helix-loop-helix proteins. Mol. Cell. Biol. 19, 4600-4610

Jedlicki, A., Hinrichs, M.V., Allende, C.C., and Allende, J.E. (1992) The cDNAs coding for the $\alpha$ and $\beta$ subunits of Xenopus laevis casein kinase II. FEBS Lett. 297, 280-284

Jimenez, G., and Ish-Horowicz, D. (1997) A chimeric Enhancer-of-split transcriptional activator drives neural development and achaete-scute expression. Mol. Cell. Bio. 17, $4355-4362$

Kalive, M., Trott, R.L., and Bidwai, A.P. (2001) A gene located at 72A in Drosophila melanogaster encodes a novel zinc-finger protein that interacts with protein kinase CK2. Mol. Cell. Biochem. 227, 99-105

Karandikar, U.C., Trott, R.L., Yin., J., Bishop, C.P., and Bidwai, A.P. (2004) Drosophila $\mathrm{CK} 2$ regulates eye motphogenesis bia phosphorylation of $\mathrm{E}(\mathrm{spl}) \mathrm{m} 8$. Mech. Dev. 212, 273-286

Klambt, C., Knust, E., Tietze, K. and Campos-Ortega, J.A. (1989) Closely related transcripts encoded by the neurogenic gene complex enhancer of split of Drosophila melanogaster. EMBO J. 8, 203-210

Knust, E., Schrons, H., Grawe, F., and Campos-Ortaga, J.A. (1992) Seven genes of the Enhancer of split complex of Drosophila melanogaster encode helix-loop-helix proteins. Genetics 132, 505-518

Knust, E.,Tietze,K., and Campus-Ortega, J.A. (1987) Molecular analysis of the neurogenic locus Enhancer of split of Drosophila melanogaster. EMBO J. 6, 4113-4123 
Knust, E., Bremer, K.A., Vassin, H., Ziemer, A., Tepa, U. and Campos-Ortega, J.A. (1992) The Enhancer of split locus and neurogenesis in Drosophila melanogaster. Dev. Biol. 122, 262-273

Lecourtois, M. and Schweisguth, F. (1995) The neurogenic Suppressor of Hairless DNAbinding protein mediates the transcriptional activation of the Enhancer of split Complex genes triggered by Notch signaling. Genes Dev. 9, 2598-2608

Lee, J.E. (1997) Basic helix-loop-helix genes in neural development. Curr. Opin. Neurobiol. 7, 13-20

Lehmann, R., Jimenez, F., Dietrich, U. and Campos-Ortega, J. (1983) On the phenotype and development of mutants of early neurogenesis in Drosophila melanogaster. Roux's Arch. Dev. Biol. 192, 62-74

Li, M., Strand, D., Krehan, A., Pyerin W., Heid, H., Neumann, B., Mechler, B.M. (1999) Casein kinase 2 binds and phosphorylates the nucleosome assembly protein-1 (NAP1) in Drosophila melanogaster. J. Mol. Biol. 293, 1067-1084

Ligoxygakis, P., Bray, S.J., Apidianakis, Y., and Delidakis, C. (1999) Ectopic expression of individual $\mathrm{E}(\mathrm{spl})$ genes has differential effects on different cell fate decisions and underscores the biphasic requirement for notch activity in wing margin establishment in Drosophila. Development 126, 2205-2214

Lin, A., Frost, J., Deng, T., Smeal, T., Al-Alawi, N., and Karin, M. (1992) Casein kinase II is a negative regulator of c-Jun DNA binding and AP-1 activity. Cell 70, 777-789

Lin, W.J., Tuazon, P.T., and Traugh, J.A. (1991) Characterization of the catalytic subunit of casein kinase II expressed in Escherichia coli and regulation of activity. J. Biol. Chem. 266, 5664-5669

Lindsley, D.L., and Grell, E.H. (1972) Genetic Variations of Drosophila melanogaster. Carnegie Institution of Washington.

Litchfield, D.W. (2003) Protein kinase CK2: structure, regulation and role in cellular decisions of life and death. Biochem. J. 369, 1-15

Litchfield, D.W.; and Luscher, B. (1993) Casein kinase II in signal transduction and cell cycle regulation. Mol. Cell. Biochem. 127/128, 187-199

Litchfield, D.W., Lozeman, F.J., Cicirelle, M.F., Harrylock, M., Ericsson, L.H., Piening, C.J.and Krebs, E.G. (1991) Phosphorylation of the $\beta$ subunit of casein kinase II in human A431 cells: identification of the autophosphorylation site and a site phosphorylated by p34 ${ }^{\text {cdc2 }}$. J. Biol. Chem. 266,20380-20389 
Liu, Z.P., Galindo, R.L., and Wasserman, S.A. (1997) A role for CKII phosphorylation of the cactus PEST domain in dorsoventral patterning of the Drosophila embryo. Genes \& Dev. 11, 3413-3422

Lozeman, F.J., Litchfield, D.W., Piening, C., Takio, K., Walsh, K.A. and Krebs, E.G. (1990) Isolation and characterization of human cDNA clones encoding the $\alpha$ and $\alpha$ ' subunits of casein kinase II. Biochemistry 29, 8436-8447

Luscher, B., Christenson, E., Litchfield, D.W., Krebs, E.G., and Eisenman, R.N. (1990) Myb DNA binding ingibited by phosphorylation at a site deleted during oncogenic activation. Nature 344, 517-521

Marais, R.M, Hsuan, J.J., McGuigan, C., Wynne, J. and Treisman, R. (1992) Casein kinase II phosphorylation increases the rate of serum response factor-binding site exchange. EMBO J.11,97-105.

Maridor, G., Park, W., Krek, W., and Nigg, E.A. (1991) Casein kinase II cDNA sequences, developmental expression, and tissue distribution of mRNAs for $\alpha, \alpha^{\prime}$ and $\beta$ subunits of the chicken enzyme. J. Biol. Chem. 266, 2362-2368

Marin, O., Meggio, F., Sarno, S., Cesaro, L., Pagano, M.A. and Pinna, L.A. (1999) Tyrosine versus serine/threonine phosphorylation by protein kinase casein kinase-2. A study with peptide substrates derived from immunophilin Fpr3. J. Biol. Chem. 274, 29260-29265

Marin, O., Meggio, F., Sarno, S. and Pinna, L.A. (1997) Physical dissection of the structural elements responsible for regulatory properties and intersubunit interactions of protein kinase CK2 beta-subunit. Biochemistry 36, 7192-7198

Martin-Bermudo, M.D., Carmena, A. and Jimenez, F. (1995) Neurogenic genes control gene expression at the transcriptional level in early neurogenesis and in mesectoderm specification. Development 121,219-224

Martin-Bermudo, M.D., Martinex, C., Rodriguex, I. and Jimenez, F. (1991) Distribution and function of the lethal of scute gene product during early neurogenesis in Drosophila. Development 113, 445-454

Massari, M.E., and Murre, C. (2000) Helix-Loop-Helix Proteins: Regulators of Transcription in Eucaryotic Organisms. Mol. Cell. Biol. 20, 429-440

Meggio, F., and Pinna, L.A. (2003) One-thousand-and-one substrates of protein kinase CK2? FASEB 17, 349-368

Meggio F., Boldyreff, B., Issinger, O.-G., and Pinna L.A. (1994) Casein kinase-2 downregulation and activation by polybasic peptides are mediated by acidic residues in the 55- 
64 region of the $\beta$-subunit. A study with calmodulin as phosphorylatable substrate. Biochemistry 33, 4336-4342

Meggio, F., Marin, O., and Pinna, L.A. (1994) Substrate specificity of protein kinase CK2. Cell. Mol. Biol. Res. 40, 401-409

Meggio, F., Boldyreff, B., Marin, O., Marchiori, F., Perich, J.W., Issinger, O.-G., and Pinna, L.A. (1992) The effect of polylysine on casein kinase 2 activity is influenced both by the structure of the protein/peptide substrates and the subunit composition of the enzyme. Eur. J. Biochem. 205, 939-945

Messenger, M.M., Sauinier, R.B., Gilchrist, A.D., Diamond, P., Gorbsky, G.J. and Litchfield, D.W. (2002) Interactions between protein kinase CK2 and Pin1: evidence for phosphorylation-dependent interactions. J. Biol. Chem. 277, 23054-23067

Murre, C., Bain, G., Difk, M.A. v., Engel, I., Furnari, B.A., Massari, M.E., Matthews, J.R., Quong, M.W., Rivera, R.R., and Stuiver, M.H. (1994) Structure and function of helix-loop-helix proteins. Biochim. Biophys. Acta. 1218, 129-135

Nakao, K., and Campos-Ortega, J.A. (1996) Persistent expression of genes of the Enhancer of split Comples suppresses neural development in Drosophila. Neuron 16, 275-286

Nagel, A.C. and Preiss, A. (1999) Notch ${ }^{\text {spl }}$ Is Deficient for Inductive Processes in the Eye, and $\mathrm{E}(\mathrm{spl})^{\mathrm{D}}$ Enhances split by Interfering with Proneural Activity. Dev. Biol. 208, 406-415

Niefind, K., Guerra, B., Ermakowa, I. and Issinger, O.G. (2001) Crystal structure of human protein kinase CK2: insights into basic properties of the CK2 holoenzyme. Embo. J. 20, 5320-5331

Oellers, N., Dehio, M., and Knust, E. (1994) bHLH proteins encoded by the Enhancer of split complex of Drosophila negatively interfere with transcriptional activation mediated by proneural genes. Mol. Gen. Genet. 244, 465-473

Padmanabha, R., Chen-Wu, J.L., Hanna, D.E. and Glover, C.V. (1990) Isolation, sequencing and disruption of the yeast CKA2 gene: casein kinase II is essential for viability in Saccharomyces cerevisiae. Mol. Cell. Biol. 10, 4089-4099

Parody, T.R., and Muskavitch, M.A. (1993) The pleiotropic function of Delta during postembryonic development of Drosophila melanogaster. Genetics 135,527-39.

Paroush, Z., Finley, R.L., Jr., Kidd, T., Wainwright, S.M., Ingham, P.W., Brent, R., and Ish-Horowicz, D. (1994) Groucho is required for Drosophila neurogenesis, segmentation, and sex determination and interacts directly with hairy-related bHLH proteins. Cell. 79, 805-815 
Pinna, L.A. (1997) Molecules in Focus: Protein Kinase CK2. Int. J. Biochem. Cell Biol. 29, 551-554

Pinna, L.A. (1994) A Historical View Of Protein Kinase CK2. Cellular and Molecular Biology Research 40, 383-390

Pinna, L.A. (1990) Casein kinase 2: an "eminence grise" in cellular regulation? Biochem. Biophys. Acta 1054, 267-284

Poulson, D.F. (1967) Developmental effects of mutants at the Notch locus in D. mel. Dros. Inf. Serv. 42, 81

Preiss, A., Hartley, D.A., and Artavanis-Tsakonas, S. (1988) The molecular genetics of Enhancer of split, a gene required for embryonic neural development in Drosophila. EMBO J. 7, 3917-3927

Prigent, C., Lasko, D.D., Kodama, K., Woodgett, J.R., and Lindahl, T. (1992) Activation of mammalian DNA ligase through phosphorylation by casein kinase II. EMBO J. 11, 2925-2933

Ready, D.F., Hanson, T.E., and Benzer, S. (1976) Development of the Drosophila retina, a neurocrystalline lattice. Dev. Biol. 53, 217-240

Roach, P.J. (1991) Moutisite and hierarchal protein phosphorylation. J. Biol. Chem. 266, $14139-14142$

Rodnight, R.; and Lavin, B.E. (1964) Phosvitin kinase from brain: Activation by ions and subcellular distribution. Biochem. J. 93, 84-91

Roussou, I., and Draetta, G. (1994) The Schizosaccharomyces pombe casein kinase II $\alpha$ and $\beta$ subunits: Evolutionary conservation and positive role of the $\beta$ subunit. Mol. Cell. Biol. 14, 576-586

Ruiz-Gomez, M., and Ghysen, A. (1993) The expression and role of a proneural gene, achaete, in the development of the larval nerbous system of Drosophila. EMBO J. 12, $1121-1130$

Sambrook, Fritsch, and Maniatis. (1989) Molecular Cloning. vol. 1, Cold Spring Harbor, NY.

Sarno, S., Vaglio, P., Cesaro, L. Marin, O., and Pinna, L.A. (1999) A multifunctional network of basic residues confers unique properties to protein kinase CK2. Mol. Cell Biochem. 191, 13-19 
Saxena, A.; Padmanabha, R.; and Glover, C.V.C. (1987) Isolation and sequencing of cDNA clones encoding alpha and beta subunits of Drosophila melanogaster casein kinase II. Mol. Cell. Biol. 7, 3409-3417

Schrons, H., Knust, F., and Campos-Ortega, J.A. (1992) The Enhancer of split complex and adjacent genes in the 96F region of Drosophila melanogaster are required for segregation of neural and epidermal progenitor cells. Genetics 132, 481-503

Skeath, J.B., and Carroll, S.B. (1991) Regulation of achaete-scute gene expression and sensory organ pattern formation in the Drosophila wing. Genes Dev. 5, 984-995

Skeath, J.B., and Carroll, S.B. (1992) Regulation of proneural gene expression and cell fate during neuroblast segregation in the Drosophila embryo. Development 114, 939-946

Shi, X., Potvin, B., Huang, T., Hilgard, P., Spray, D.C., Suadicani, S.O., Wolkoff, A.W., Stanley, P. and Stockert, R.J. (2001) A novel casein kinase 2 alpha-subunit regulates membrane protein traffic in the human hepatoma cell line HuH-7. J. Biol. Chem. 276, 2075-2082

Snell, V. and Nurse, P. (1994) Genetic analysis of cell morphogenesis in fission yeast--a role for casein kinase II in the establishment of polarized growth. EMBO J.13, 2066-74.

Spradling, A.C. (1986) P element-mediated transformation , pp. 175-197 in Drosophila: A Practical Approach, edited by D.B. Roberts. IRL Press, Oxford

Struhl, G. and Adachi, A. (1998) Nuclear Access and Action of Notch In Vivo. Cell 93, 649-660

Tata, F., and Hartley, D.A. (1995) Inhibition of cell fate in Drosophila by Enhancer of Split genes. Mechanisms of Development 51, 305-315

Tietze, K., Oellers, N., and Knust, E. (1992) Enhancer of splitD, a dominant mutation of Drosophla, and its use in the study of functional domains of a helix-loop-helix protein.

Proc. Natl. Acad. Sci. USA 89, 6152-6156

Toczyski, D.P., Galgoczy, D.J. and Hartwell, L.H. (1997) CDC5 and CKII control adaptation to the yeast DNA damage checkpoint. Cell 90, 1097-1106

Tomlinson, A. (1988) Cellular interactions in the developing Drosophila eye. Development 104, 183-193

Traugh, J.A., Tahara, S.M., Sharp, S.B., Safer, B., and Merrick, W.C. (1976) Factors involved in initiation of haemoglobin synthesis can be phophorylated in vitro. Nature 263, 163-165 
Trott, R.L., Kalive, M., Paroush, Z., Bidwai, A.P. (2001) Drosophila melanogaster Casein Kinase II Interacts with and Phophorylates the Basic Helix-Loop-Helix Proteins $\mathrm{m} 5, \mathrm{~m} 7$, and $\mathrm{m} 8$ Derived from the Enhancer of split Complex. J. Biol. Chem. 276, 21592167

Uniprot, The Universal Protein Resource: http://www.pir.uniprot.org/cgi$\underline{\text { bin/upEntry?id }=\mathrm{P} 13098}$

Valero, E., de Bonis, S., Filhol, O., Wade, R.H., Langowski, J., Chambaz, E.M. and Cochet, C. (1995) Quaternary structure of protein kinase CK2. Characterization of multiple oligomeric states and relation with its catalytic activity. J. Biol. Chem. 270, 8345-8352

Wilson, L.K., Dhillon, M. Thorner, J. and Martin, G.S. (1997) Casein Kinase II Catalyzes Tyrosine Phosphorylation of the yeast Nucleolar Immunophilin Fpr3. J. Biol. Chem. 272, 12961-12967

Wirkner, U, Voss, H., Lichter, P., Ansorge, W. and Pyerin, W. (1994) The human gene (CSNK2A1) coding for the casein kinase II subunit alpha is located on chromosome 20 and contains tandemly arranged Alu repeats. Genomics 19, 257-265

Wolpert, L. (2002) Development of the nervous system. In Principles of Development (pp. 375-416). Oxford.

Xu, T., Caron, L.A., Fehon, R.G., and Artavanis-Tsakonas, S. (1992) The involvement of the Notch locus in Drosophila oogenesis. Development 115, 913-922

Xu, X., Toselli, P.A., Russell, I.D. and Seldin, D.C. (1999) Globozoospermia in mice lacking the casein kinase II alpha' catalytic subunit. Nat. Genet. 23, 118-121

Yang-Feng, T.L., Naiman, T., Kopatz, I., Eli, D., Dafri, N. and Canaani, D. (1994) Assignment of the human casein kinase II alpha' gene (CSNK2A1) to chromosome 16p132-p123. Genomics 19, 173

Zhou, X.Z., Lu, P.J., Wulf, G. and Lu, K.P. (1999) Phosphorylation dependent prolyl isomerization: a novel signaling regulatory mechanism. Cell. Mol. Life Sci. 56,788-806

Ziemer, A. Tietze, K., Knust, E., Campos-Ortega, J.A. (1988) Genetic analysis of Enhaner of split, a locus involved in neurogenesis in Drosophila melanogaster. Genetics 119, 63-74 